\title{
İki Rum Konutunun İşlevsel Dönüşümünün Mekânsal ve Çevresel Bağlamda Değerlendirilmesi: Kırklareli Yayla Mahallesi Örneği
}

\author{
Gülcan MINSOLMAZ YELER ${ }^{1}$
}

\section{Öz}

Bu çalışmada, Kırklareli Yayla Mahallesinde, Gusto Celepoğlu Konağı ve Papazın Evi olarak bilinen iki adet Rum konutunun yeniden işlevlendirilerek restoran ve kafeye dönüşüm süreci ele alınmaktadır. Öncelikle, konutların mekânsal özellikleri yerinde gözlem ve kat planları üzerinden karşılaştırmalı olarak ele alınmaktadır. Bu yöntem ile mekânsal değişim ve dönüşümler analiz edilmekte, süreç içerisinde yapılan müdahaleler tespit edilmektedir. Sonrasında, sözlü görüşmelerden de yararlanılarak yapılan mekânsal ve çevresel bağlamda değerlendirmeler ile eski ve yeni işlev arasında uyum durumu belirlenmektedir. Çalışmanın sonucunda, konutların özgün hacimsel ve mekânsal özellikleri göz önünde bulundurularak geliştirilen tasarım fikirleri ile eski ve yeni işlev arasında uyumun sağlandığı ortaya konmuştur. Ayrıca, yeni işlevin belirlenmesinde, çevrenin fiziksel, sosyo-kültürel ve ekonomik koşullarının da dikkate alındığı saptanmıştır.

Anahtar Kelimeler: Rum konutu, Koruma, Yeniden işlevlendirme, Mekânsal değişim, Bağlam, Kırklareli.

\section{An Evaluation of the Functional Transformation of Two Greek Houses in Spatial and Environmental Context: The Case of Kırklareli Yayla District}

\begin{abstract}
In this study, the transformation process of two Greek houses, known as Gusto Celepoğlu Mansion and Priest's House, in Kırklareli Yayla District, into a restaurant and cafe respectively is discussed. First of all, the spatial characteristics of the houses are discussed comparatively through on-site observation and floor plans. With this method, spatial changes and transformations are analyzed, and the interventions made in the process are determined. Afterwards, the compatibility between the old and the new function is determined by the evaluations in the spatial and environmental context, which are also made through oral interviews. As a result of the study, it has been revealed that the harmony between the old and new functions is achieved with the design ideas developed by taking into account the original volumetric and spatial characteristics of the houses. In addition, it was determined that the physical, sociocultural, and economic conditions of the environment were taken into account in the determination of the new function.
\end{abstract}

Keywords: Greek house, Conservation, Re-functioning, Spatial change, Context, Kırklareli.

\footnotetext{
${ }^{1}$ Kırklareli Üniversitesi, Mimarlık Fakültesi, Mimarlık Bölümü, Kırklareli.

*ilgili yazar/Corresponding author: gulcan.yeler@klu.edu.tr 


\section{Giriş}

Geleneksel mimarlık, tarih boyunca insanın çevresi ile doğrudan olan ilişki ve deneyiminden kaynaklanarak, çevre koşullarına en uygun şekilde çözümler üreten ve yaşam kültürünü yansıtan, insan-doğa-kültür bütünü olarak tanımlanabilmektedir (Minsolmaz Yeler ve Özek, 2007, s. 125). Ayrıca, toplumun özelliklerini ve farkındalığını yaratan yetkin bir ürün, toplumsal yapımızın da bir göstergesidir (Apay vd., 2019, s. 161). Ahunbay (1999, s. 173), bu kapsamda, geleneksel yapıları belirli bir dönemin kentsel ve mimari düzeninin, yapım tekniklerinin, sosyal yaşamının önemli aktarıcısı ve bunları açıklayan bir belge olarak değerlendirilmektedir. Kuban (2014, s. 20), mimarinin her toplumun tarihi gelişmesinin ortaya koyduğu gereksinimlerin, bunları karşılayan yapı programları ve bu programlarla bütünleşmiş kültür özelliklerinin yapı üretimini yönlendirdiğini belirtmektedir. Özker (2020, s. 225)'e göre de tarihi yapılar, geçmişin, ait olduğu dönemin ve sonraki süreçlerin anlamsal izlerini yansıtır, kültürel kodlarını ve farklı etnik yaşantıların izlerini kent kimliği ve mekânsal özellikleri ile birlikte geleceğe aktarmaktadırlar.

Fakat tarihi ve kültürel mirasımızın korunup yaşatılması konusunda bazı problemler yaşanmaktadır. Kentleşmeyle birlikte ortaya çıkan hızlı nüfus artışı, plansız gelişmeler, geleneksel doku içinde sosyal ve fiziksel çevrenin değişimi, değişen kullanıcı gereksinimleri, sürekli el değişimi, koruma kültür ve bilincimizin eksikliği, kişisel faydaların toplum yararının önünde tutulması, bilinçsiz tahribat, yanlış kullanım, bakımsızlık, mali kaynakların yetersizliği, yapılan planlardaki uygulama sorunları, mevzuattaki eksiklikler gibi nedenler geleneksel yapıların zamanla değerlerini kaybetmelerine neden olmaktadır (Özker, 2020, s. 225; Güneş Çiçek, 2010, s. 24-25).

Bu nedenlerle Ahunbay (1999, s. 173), Madran ve Özgönül'ün de belirttiği gibi; geçmişi öğrenmek, deneyimlerinden yararlanmak, gelecek için örnek almak, bir belge olarak gelecek nesillere aktarmak gibi birçok nedene dayalı olarak geçmişin tanıkları olarak kabul edeceğimiz yapıların/sivil mimarlık örneklerinin korunmaları gerekmektedir (Madran ve Özgönül'den aktaran Aydın ve Yaldız, 2010, s. 2). Yapıların korunmasında en etkili yöntem ise Altınoluk'un da vurguladığı gibi, yaşatarak korumadır. Bu yaklaşımda amaç, yapıya bir işlevsel içerik kazandırmak, onu topluma yararlı kılmak, toplumun onda yaşamasını, çevrenin ondan yararlanmasını sağlamaktır (Altınoluk'tan aktaran Akın ve Özen, 2013, s. 26). Kuban, bir tarihi yapının tek başına değil çevresiyle birlikte korunması gerektiğini, değişme hızı içinde, eski ve yeninin ortak yaratacakları yeni bir bütünün oluşturulması için bunun gerekli olduğunu belirtmektedir (Kuban'dan aktaran Akın ve Özen, 2013, s. 26) . Bu yönleriyle yeniden işlevlendirilerek insanlar tarafından aktif olarak kullanılan geleneksel konutlar, çevresiyle yaşayan birer varlık konumuna gelerek bulundukları çevrenin değerini önemli derecede artırmakta ve bölgenin kimlik kazanmasını sağlamaktadırlar. Geçmişi dondurarak korumak yerine bütünleşik koruma anlayışı ile kentin özgün kimliğini yansıtan geleneksel konutların çevrelerinden yalıtılmadan korunması, tarihi, kültürel ve geleneksel mimari özellikleri ile bütüncül olarak ele alınıp uygun işlevlerle yeniden kullanılması, bu yapıların "izlenen" değil "yaşanan" bir yapıya dönüşmesine ve kent yaşamı ile bütünleşmesine olanak tanımaktadır (Kıvılcım, 2019, s. 55).

Aydın ve Yaldız (2010, s. 1-2)'a göre; yapısal olarak ayakta olan bir binanın ilk yapılış, amacına dönük olarak işlevsel, çevresel ve ekonomik nedenlerle kullanılamaması, farklı bir işlevle yeniden değerlendirilmesi gerektiği gerçeğini ortaya koymaktadır. Yeniden işlevlendirme ile var olan yapı stoku değerlendirilerek doğal çevreye verilecek zarar azaltılmakta, ekonomik açıdan fayda ve kültürel süreklilik de sağlanmaktadır. Mısırlısoy ve Günçe (2016, s.149-150) de uyarlanabilir yeniden kullanım kavramına 
dikkat çekmekte, bu yaklaşımla, hem binanın hem de çevrenin sürdürülebilir bir şekilde korunmasının sağlanacağını belirtmektedirler. Ayrıca, ekonomik ve sosyal intiyaçlara dayalı yeni kullanımlar için saygılı ve uyarlanabilir yeniden kullanımın, yapının ve tarihi çevrenin orijinalliğini sağlayacağını, çevresel ve sosyal faydalarla birlikte kültürel mirasın korunmasına yardımcı olacağını da vurgulamaktadırlar. Koruma faaliyetlerinin başarısı ve sürekliliği, yerel halkın katılım düzeyi ve onların takdiri, sürekli kullanımı ve sakinlerin bakım çabalarıyla yakından ilgilidir (Var ve Kobayashi, 2019, s. 72). Bu kapsamda, Tanrısever ve arkadaşları (2016, s. 1071)'nın da belirttiği gibi, yeniden işlevlendirmenin başarılı olması hem çevreyi hem de çevrede yaşayan insanların yapıyı kabullenme sürecini hızlandırmakta, kabullenilen yapı kullanılıp, korunup sürdürülebilirliğini devam ettirmektedir. Bu yönleriyle yeni işlevin belirlenmesinde; işlevlendirme süreçlerinin, seçilen işlevin sürekliliğinin sağlanmasının ve dönüşümde yapıya uygulanan müdahaleler önem kazanmaktadır (Dinç Kalaycı ve Utku, 2016, s. 345).

\section{2. Çalışmanın Amacı ve Yöntemi}

Bu çalışma, Osmanlı döneminde Rumlar, mübadele sonrasında da Türkler tarafından kullanılmış, ancak uzun bir süre tahrip olduğundan dolayı içinde yaşamın olmadığı Gusto Celepoğlu Konağı ve Papazın Evi olarak bilinen iki adet Rum konutunun yeniden işlevlendirilmesine odaklanmaktadır. Çalışmanın amacı, özgün işlevinden restoran ve kafeye dönüştürülme sürecinde, geleneksel yaşam tarzına göre az sayıda kullanıcıya göre belirli boyutlarda tasarlanan sözü edilen konutların, kalabalık ve farklı kullanıcıya hitap eden kamusal mekânlara dönüştürülürken ne tür tasarım yaklaşımlarının belirlendiğini ortaya koymaktır. Ayrıca, çalışma mekânsal değişim ve dönüşümlerin ne ölçüde yapıldığı, yeni işlevin mekânlar ve çevre ile ne ölçüde uyumlu olduğu ve dönüşüm sürecinde özgünlüğün ne ölçüde korunduğu gibi sorulara da cevap aramaktadır. Bu kapsamda, karşılaştırmalı bir analiz yöntemi ile her bir konut eski ve yeni işlevsel kullanımları bakımından incelenmektedir. Bu süreçte, literatür araştırması ile elde edilen belgelerden, fotoğraflardan, rölöve ve restorasyon projelerinden yararlanılmıştır ve saha araştırması yoluyla seçilen binalar gözlemlenmiştir. Sonrasında, söz konusu işlevsel/mekânsal değişimlerin kullanıcılar tarafından nasıl karşılandığı, ayrıca, konutların çevresi ile bir bütün olduğu düşünülerek yeni işlevin çevre özelikleri bakımından ne kadar uyumlu olduğu, yeni işlevin bulunduğu bölgeye, mahalleye fiziksel, sosyo-kültürel ve ekonomik açılardan ne tür etkileri olduğu anlaşıımaya çalışıımaktadır. Bu kapsamda, saha çalışması esnasında işletme sahipleri ve çalışanları ile yapılan sözlü görüşmelerden de yararlanılmıştır. Sonuç olarak tüm bulguların mekânsal ve çevresel bağlamda değerlendirmeleri ile eski ve yeni işlev arasında uyum durumu anlaşılmaya çalışılmıştır.

\section{3. Çalışma Alanı ve Önemi}

Çalışmanın ana konusunu oluşturan Gusto Celepoğlu Konağı ve Papazın Evi Bistro Cafe\&Bar Kırklareli kentinin kuzeyinde yer alan Yayla Mahallesinde bulunmaktadır. Kırklareli kentinin geçmşinde, uzun bir süre Rum, Bulgar, Yahudi ve Türk nüfus birlikte yaşamıştır. Daha önceleri Kırklareli, Kırkkilise olarak adlandırılmaktadır ve Edirne Vilayetine bağlı bir sancaktır. 1880 yılında, bugün merkez ilçe olarak kabul ettiğimiz Kırıkkilise Bölgesinde, 13.554 Rum, 11.678 Bulgar, 5.745 Türk, 540 Yahudi ve 492 Roman nüfusu bulunmaktadır (Hristodulu'dan aktaran Doğruöz vd, 2020, s. 95). 19061907 Osmanlı nüfus sayımlarına göre Kırklareli Sancağında genel nüfusun 78.338'i Müslüman, 70.501'i Rum, 149'u Ermeni, 29.736'sı Bulgar, 1.699'u Yahudi ve 573'ü de Roman'dır (Karpat, 2003, s.205-206). Savaşlara bağlı olarak yaşanan göçler nedeniyle Sancak dahilindeki Müslüman nüfus yoğun bir şekilde artmış, ilk defa Müslümanlar en 
kalabalık unsur olmasına karşın, çoğunluğu yine gayrimüslimler oluşturmuştur (Toptaş, 2012, s. 19).

Yayla Mahallesi de, ilk yerleşim yeri olması ve mübadele öncesinde ağırlıklı olarak Rum nüfusunun yaşadığı, özgün bir mimari karakter sergileyen konutları barındırması bakımından her zaman önemini korumuştur. Yayla Meydanı ve mahalleyi kent merkezine bağlayan Yayla Caddesi o dönem için mahallede ön plana çıkan yerleşimler olmuştur (Şekil 1, 2, 3). Bu mekânlarda yer alan neo-klasik tarzda yapılan konutlar, çoğu ticaretle uğraşan zengin Rumlara ve doktorlara ait konaklardır. Çevresinde yer alan Yunan Okulu, Arion Müzik Okulu ve Yunan Kız okulu (Toptaş, 2012, s. 42, 43, 44) gibi önemli yapılar nedeniyle Yayla Meydanı o dönem için çok önemli bir toplantı, kutlama ve miting alanı olarak kullanılmıştır. 1923 tarihinde imzalanan Lozan Antlaşması ve 30 Ocak 1923'te imzalanan Yunan ve Türk Halklarının Mübadelesine İlişkin Sözleşme ve Protokol ile kesinleşen nüfus değişimi (mübadele) nedeniyle Rum nüfus bölgeyi terk etmiştir. Bu halkların yaşadığı yerlere Yunanistan'da yaşayan Türkler yerleştirilmiştir (Behar, 1996). Kırklareli'nin 1923 yılındaki genel nüfusunun \%97.34'ünü Müslümanlar, \%0.83'ünü Bulgarlar, \%1,2'sini Museviler oluşturmuştur; Müslümanların \%83.28'i Türk, \%3,3'ü Arnavut, \%2,1'i Boşnak ve \%9,2'si de Pomak'tır (Doğruöz, 2011, s. 279). Dolayısıyla, Yayla mahallesinde Rumların yaşadığı yerlere de Türkler gelmiştir. Ancak, Yayla Meydanı ve çevresi mübadele sonrasında statüsünü korumuştur. Buradaki evlerde daha çok doktorlar, avukatlar ve memurlar yaşamıştır. Diğer evlere ise çiftçilik ile uğraşan göçmenler yerleştirilmiştir. Dolayısıyla ailelere göre farklılık gösteren mahalledeki yaşam biçimleri, sakinlerin ev ve kent mekânlarının kullanımlarını da etkilemiştir (Yeler ve M. Yeler, 2017, s. 217). Neoklasik evler ve Art Nouveau karakterli ahşap evler, ayrıca, 20. yüzyıl başlarında gelen göçmenlerin yaptığı tek katlı, avlulu basit köy evi niteliğindeki yapılar da mahallenin karakterini belirlemede etkin rol oynamıştır (Eres, 2016, s. 211). Bu çeşitlilik, Kırklareli geleneksel evlerine zenginlik katsa da farklı inanış ve kültürdeki bu insanların inşa ettirdikleri eserlerde göze çarpan çok büyük farklılıkların görülmediği anlaşılmaktadır. Hangi inanca ait olursa olsun plan tipi olarak iç sofalı ya da orta sofalı olarak inşa edilen evlerde geleneksel Türk evinin etkilerini görmek mümkündür (Apa Kurtişoğlu, 2014, s. 197).

Yayla Mahallesi, Kırklareli'nin karakteristik özelliklerinin günümüze kadar korunarak geldiği, kent kimliğinin önemli ve bütüncül bir parçası olarak sürdürülebilirliğini sağlayan bir mahalledir (Aslan vd., 2020, s. 174). Bu yönleriyle, Bölge Koruma Kurulu tarafından 19.09.1996 tarihinde "Kentsel Sit Alanı" olarak ilan edilmiştir. 2001 yılında da Koruma Amaçlı İmar Planı yapılmıştır (Eyüboğlu Erşen, 2015, s. 225). Mahallede ve meydan çevresinde yer alan pek çok yapı ve konut tescillenerek koruma altına alınmıştır. Ancak, zaman içinde yaşanan değişim ve dönüşümler doğrultusunda pek çok konut uzun bir süre kullanım dışı kalarak tahrip olmuştur. 2013 yılında başlayan projeler ile mahallede birçok cadde ile sokak yenilenmiş, mübadele sonrasında meydanın ortasında oluşturulan Yayla Parkı'nın çevre düzenlemeleri yapılmıştır. Meydan özelliği taşıyan park ve çevresi günümüzde tarihi ve turistik açıdan uğrak bir merkezdir (Gündoğdu ve Uğuz, 2020, s. 323). Hem bu bölgede hem de mahalle genelinde terk edilen konutların çoğu, yenileme çalışmaları sonrasında restoran ve kafe, butik otel, müze, idari ofis, okul gibi yeni işlevler kazandırılarak yaşatılmaya çalışılmıştır. Çalışma kapsamında seçilen ve Rum konutları olan Gusto Celepoğlu Konağı ve Papazın Evi, restoran ve kafeye dönüştürülerek mahalle ve kent yaşamına katılmıştır (Şekil 1, 2, 3). 


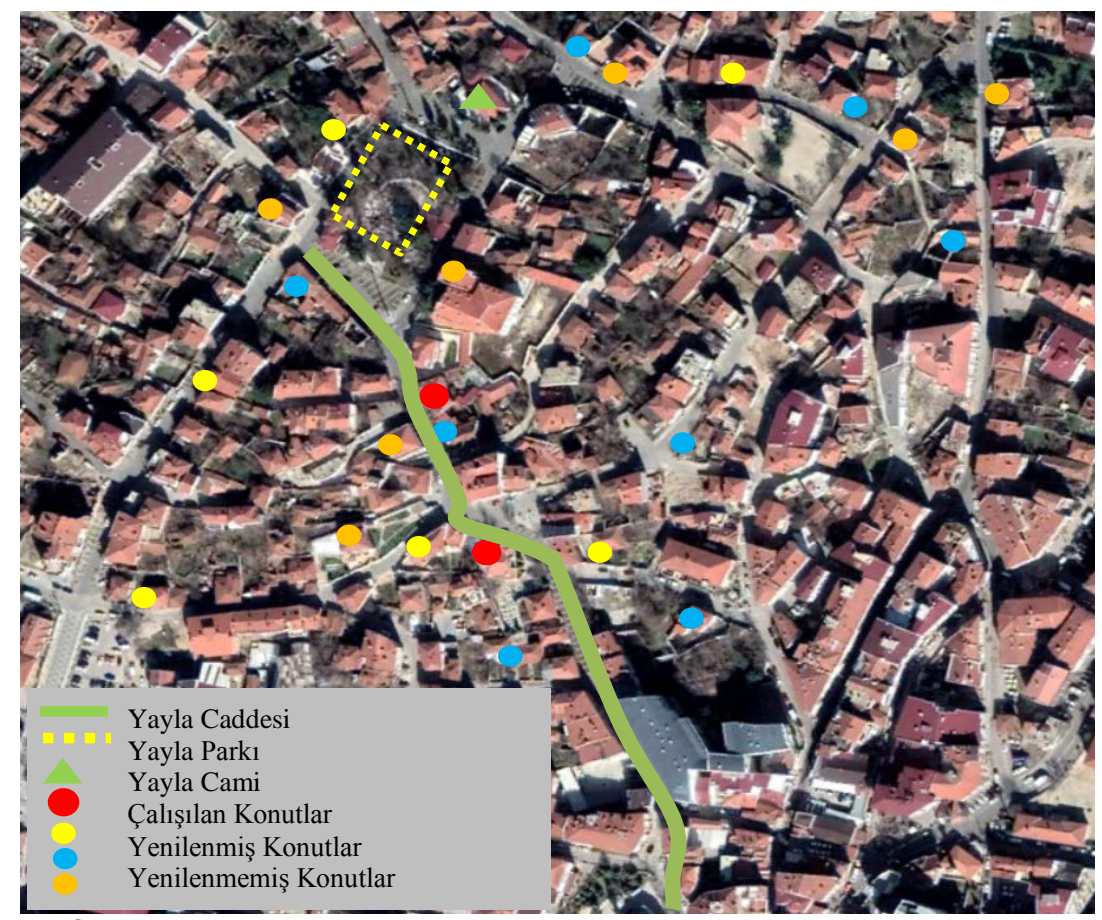

Şekil 1: Yayla Caddesi, Meydanı ve Parkı ile yakın çevresinde geleneksel konutların konumu (Gülcan M. Yeler, 2021)

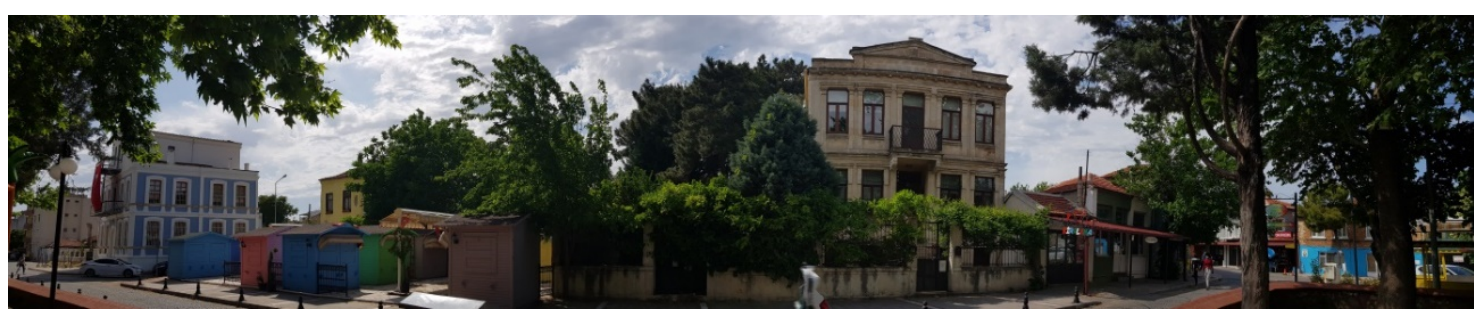

Şekil 2. Yayla caddesi, Meydanı ve Parkı ile yakın çevresinde yer alan geleneksel konutlar (Gülcan M. Yeler, 2021)

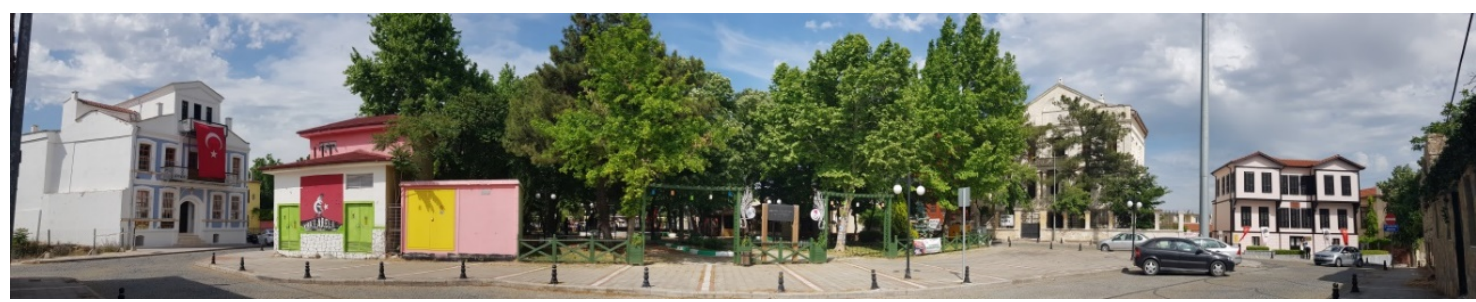

Şekil 3. Yayla Caddesi, Meydanı ve Parkı ile yakın çevresinde yer alan geleneksel konutlar

(Gülcan M. Yeler, 2021)

Gusto Celepoğlu Konağı; Yayla Caddesi üzerinde, 728 Ada ve 25 Parselde bulunmaktadır (KKVE 1, 2021). Yayla Meydanına ve parka çok yakındır. Geç Osmanlı Dönemi yapısı olan konağın yapılış tarihi, ön cephesinde yer alan üçgen alınlıkta Yunanca yazı ile 1908 olarak belirtilmiştir. Osmanlı askeri doktoru Rum S.K. Celepoğlu ait (Yannakopulu, 1994, s. 135) olan konakta, 1920 yılında Yunan Kralı Alexandros konaklamış, 1925-1926 yıllarında da yazar Halide Nusret Zorlutuna yaşamıştır. Uzun yıllar konağın sahipliğini Salih Zeki Çankır yapmıştır. Konak şu an Nusret Kocabaş'a aittir (Broşür, 2021). Uzun süre bakımsız bir durumda kalan ve kullanılmayan konut onarım çalışmaları sonrasında restoran ve kafeye dönüştürülmüştür. Aralık 2014 tarihinden itibaren Jülide-Ünal Başkur tarafından işletilmektedir (Şekil 1, Şekil 4, Şekil $5)$. 
Papazın Evi Bistro Cafe\&Bar; Yayla Caddesi üzerinde, 88 Ada 16 Parselde bulunmaktadır. 1870'li yıllarda bir papaz için inşa edilen konut, Türk ve Yunan nüfus mübadelesinden sonra Türkler tarafından aynı işlevde kullanılmıştır. Hayrettin Tuncan'a ait olan konut uzun süre bakımsız bir durumda kalmış ve sonrasında Ergin Kalınoğlu tarafından sahiplenilerek, 2008 yılında başlatılan yenileme çalışmaları sonrasında restoran ve kafeye dönüştürülmüştür. 2014 tarihinden itibaren Ergin Kalınoğlu tarafından işletilmektedir (KKVE 2, Saatçi ve Uluengin, 2016, s. 56) (Şekil 1, Şekil 4, Şekil 5).
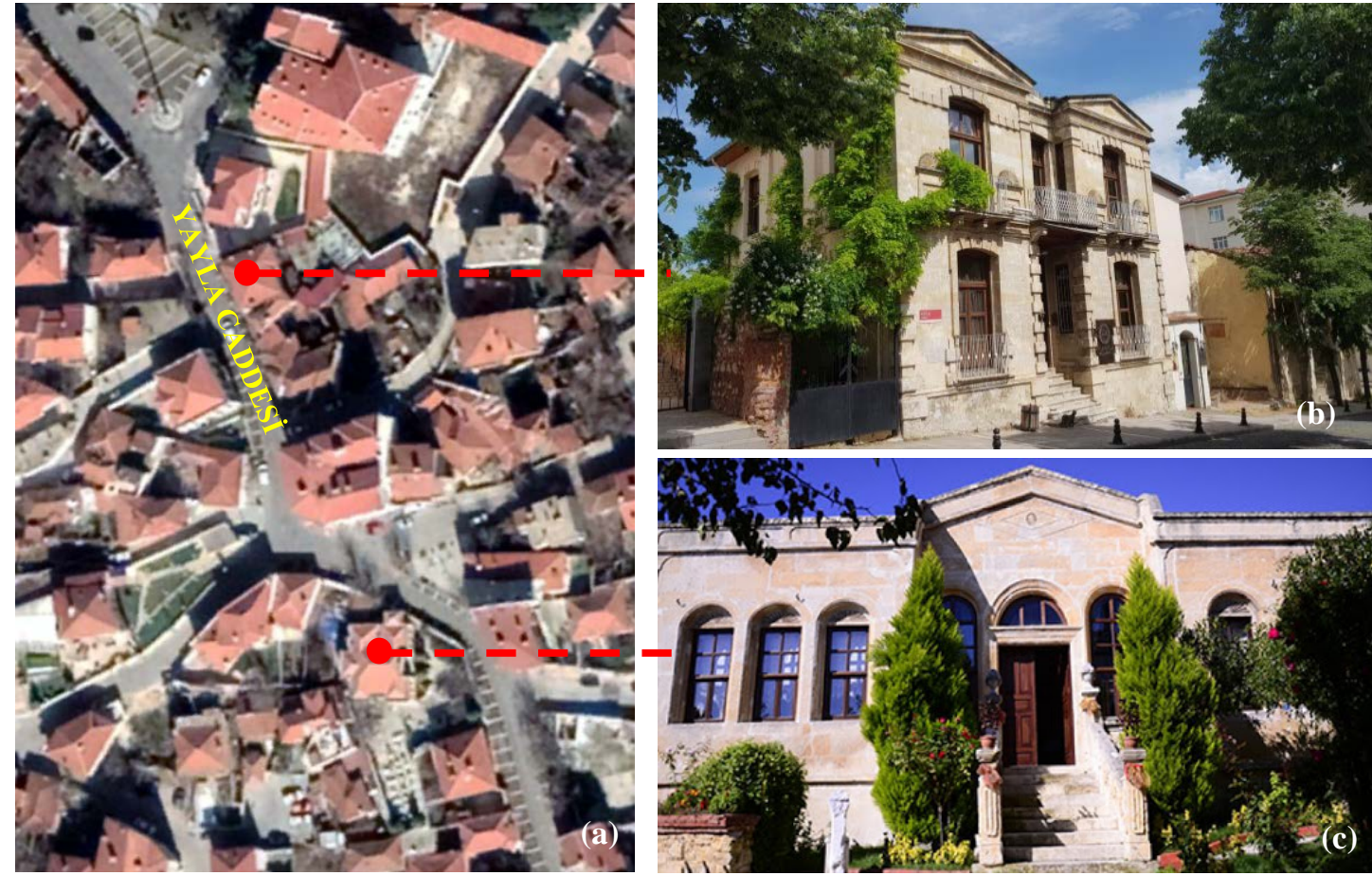

Şekil 4: Yapıların Yayla Caddesi üzerindeki konumları ve ön görünüşleri (Gülcan M. Yeler, 2021)

(a) Konum (b) Gusto Celepoğlu Konağı (c) Papazın Evi Bistro Cafe\&Bar

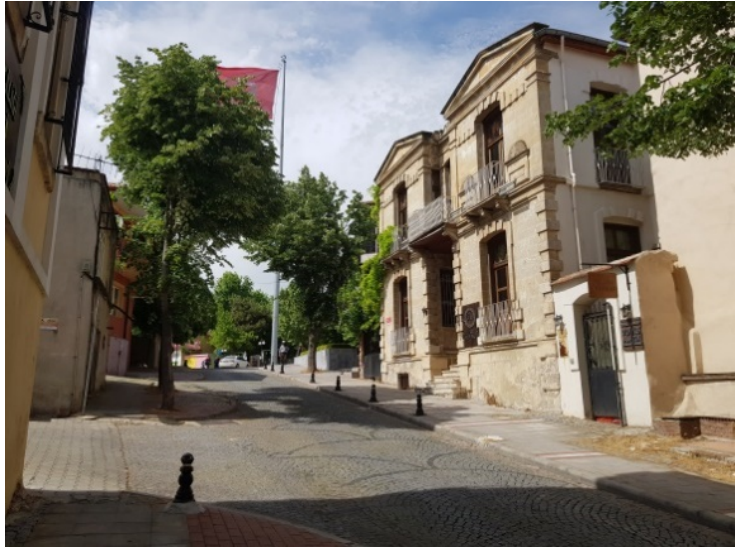

(a)

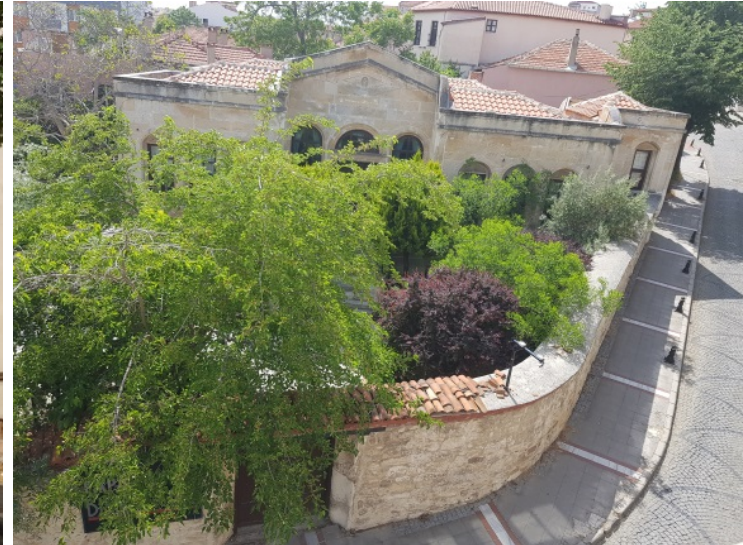

(b)

Şekil 5: Yapıların Yayla Caddesi üzerindeki konumları ve çevre ile ilişkileri (Gülcan M. Yeler, 2021)

(a) Gusto Celepoğlu Konağı (b) Papazın Evi Bistro Cafe\&Bar 


\section{4. İşlevsel Dönüşümün Mekâna Etkileri}

\subsection{Gusto Celepoğlu Konağı Mekân Analizleri}

Kâgir sisteminde inşa edilen konak, bodrum ve iki kattan oluşmaktadır. Üç farklı konseptin uygulandığı konakta bodrum kat yörenin bağcılıkla ilişkisine göre düzenlenen konsept gereği mahzen ve bar olarak, diğer iki kat ise alakart ve oda konseptine göre hizmet vermek üzere restoran olarak düzenlenmişlerdir (Tablo 1).

Tablo 1: Gusto Celepoğlu Konağı mekân analizleri (Gülcan M. Yeler, 2021)

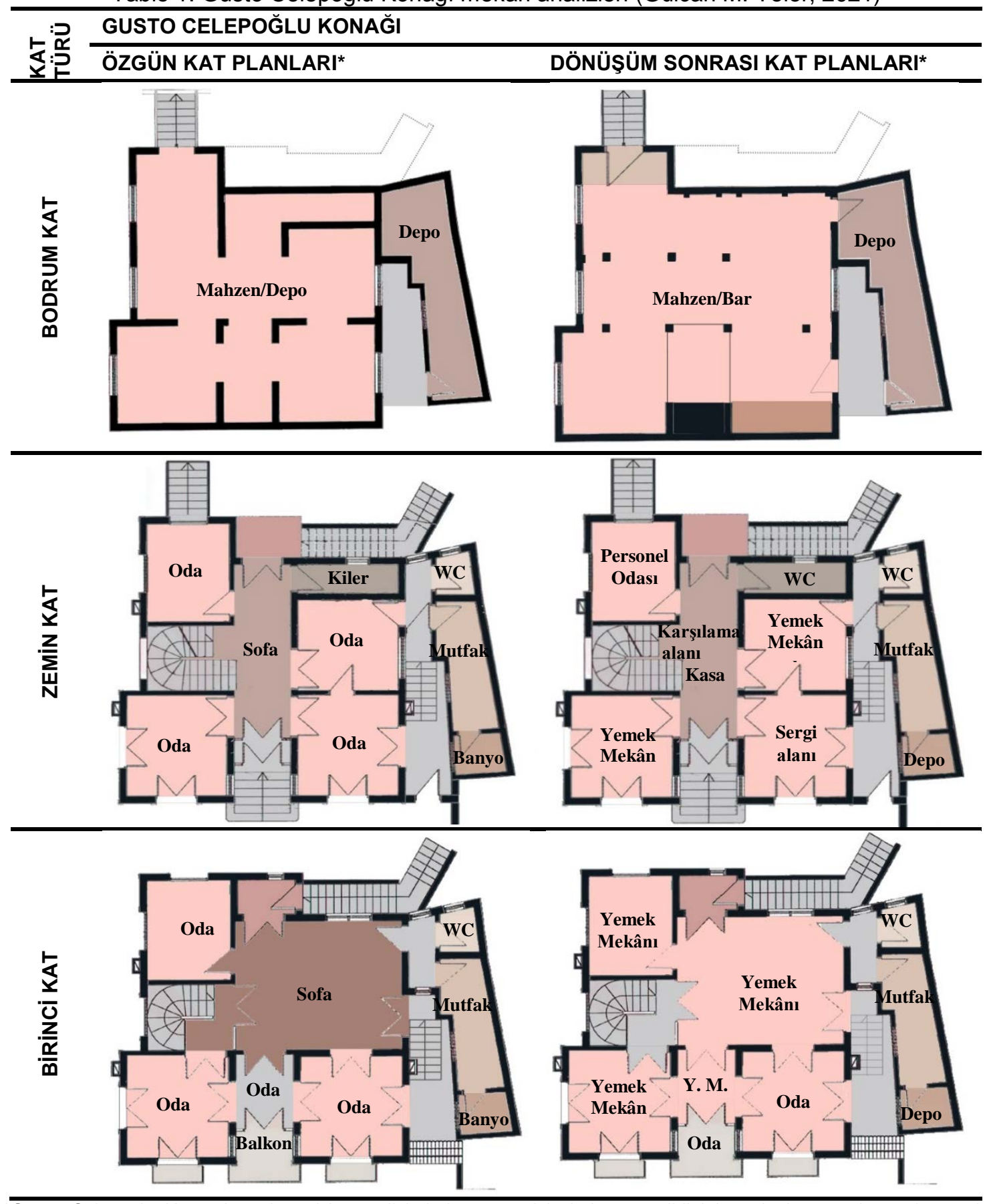

*Gusto Celepoğlu Konağı'na ait mekân analizlerinde özgün işlevlerin gösterildiği kat planlarının oluşturulmasında Tandoğan (2000) ve Sağlamcı Şahin (2000)'in çalışmalarından yararlanılmıştır. Dönüşüm sonrası kat planlarında yer verilen işlevler ve değişimler ise alan çalışması ile yazar tarafından yerinde tespit edilmiştir. 
Bahar ve yaz aylarında da bahçe konsepti ile mekân kullanımı çeşitlendirilmiştir. Yapıya giriş, caddeye bakan güneybatı cephesinden altı basamaklı bir merdivenle sağlanmıştır. Binanın sağ cephesine eklenmiş bir ek binada servis mekânları konumlandırılmıştır. Bu mekânlara ve konutun bahçesine giriş, binanın giriş cephesinin her iki yanında yer alan taş malzemeli bahçe duvarlarına açılmış demir kapılarla sağlanmıştır (Şekil 4, Şekil 5).

Binanın özgün bodrum katı (Tablo 1), Rumlar zamanında şaraphane/mahzen, Osmanlılar zamanında ve sonrasında da tahıl ambarı olarak kullanılmıştır (Yeler ve M. Yeler, 2017, s. 217). Bodrum kata, arka bahçede düzenlenen bir merdivenden inilerek ulaşıımaktadır. İç mekân duvarlarla bölünmüştür. Binanın sağında yer alan ek binanın, yan bahçeden bir girişi vardır. Yeniden işlevlendirme ile "Diyonisos Mahzen" adıyla mahzen ve bara dönüştürülen bodrum katta, özgün durumda mevcut olan iç duvarlar kaldırımış, zemin kat ahşap döşemesini taşıyan taş ayaklara oturtulan özgün dört adet ahşap dikme ile mekân tamamen açık plan haline getirilmiştir. Ayrıca, yeni eklenen ahşap dikmeler ile döşeme desteklenmiştir. Mekânın yüksekliği 1.50 m olduğundan, zemin $50 \mathrm{~cm}$ kazılarak mekânın kullanımı rahatlatımaya çalışıımıştır. Mekânın mevcut olan arka bahçeden sağlanan girişi korunmuş ancak müşteri girişi, sağ yan cephede açılan kapıdan sağlanmıştır. Girişin karşısında yer alan ve depo olarak kullanılan ek yapı ile iç mekândan da bir bağlantı kurulmuştur. İç mekanda işlev gereği servisin yapıldığı bir servis bankosuna, oturma elemanlarına ve şarapların sergilendiği camekanlara yer verilmiş, konsept gereği dekorasyonda eski dönemi yansıtan antika eşyalar, oluşturulan nişlerde ve mekanın farklı yerlerinde sergilenmiştir (Şekil 6).

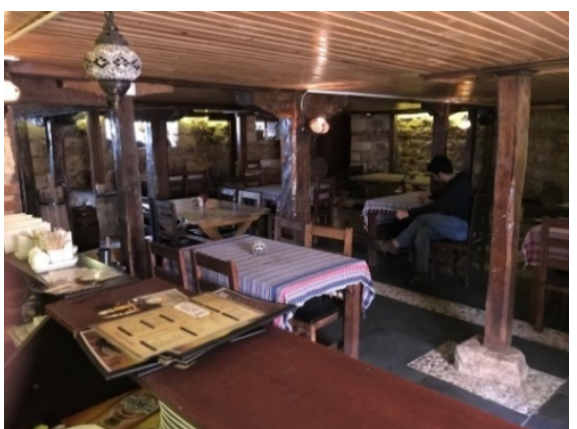

(a)

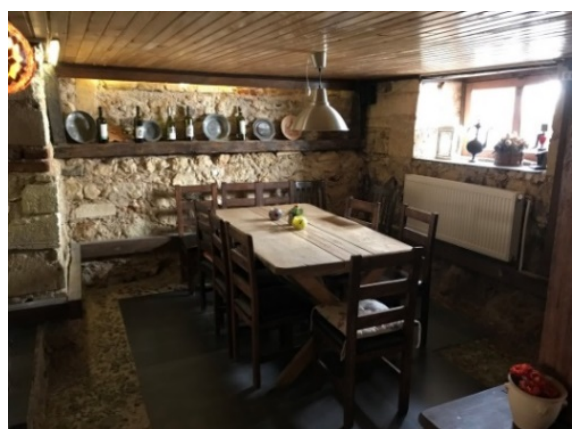

(b)

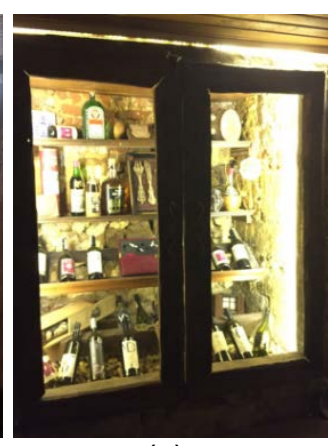

(c)

Şekil 6: Gusto Celepoğlu Konağı bodrum kat iç mekân görünüşleri (Gülcan M. Yeler, 2021)

(a) Masa düzenleri (b) Antika eşyalar (c) Şarap sergi camekânları

Binanın özgün zemin katında (Tablo 1), rüzgârlıklı bir girişten sonra geniş, camlı kapılarla sofaya ulaşılmaktadır. Dört odaya ve kilere bağlantı sağlayan sofada, iki oda arasında konumlanmış, 1. kata ulaşımı sağlayan çift kollu, ahşap konstrüksiyonlu yarım döner bir merdiven yer almaktadır. Ayrıca, girişin tam karşısında, bahçeye açılan bir kapı bulunmaktadır. Mutfak, banyo, tuvalet gibi servis mekânları ek binanın zemin katında çözülmüş, konağın bir odasından açılan bir kapı ile bu mekânlara bağlantı sağlanmıştır. Ek binanın bu katına yan bahçeden, binanın sağ cephesine yaslanmış düz kollu bir merdiven ile de ulaşılmaktadır. Yeniden işlevlendirme sonrasında girişteki sofa, karşılama alanına dönüşmüş, merdivenin altında kasaya yer verilmiştir. Oda olarak kullanılan mekanlar yemek yeme alanı, konsept sergi alanı, personel dinlenme alanı ve servis mekanları ile bağlantı sağlayan mini bar gibi mekanlara dönüşmüştür. Dekorasyonda da sergilemeye ağırlık verilmiştir. Zemin kat ile aynı kotta olan bahçeye çıkışı sağlayan kapı korunmuş, bahçeye servisler buradan sağlanmıştır. Kiler, erkekler için tuvalet kullanımına uyarlanmıştır. Ek binada yer alan tuvalet ise kadınlar için düzenlenmiştir. Mutfak işlevini korurken, buradan girişi olan banyo, depo olarak kullanılmıştır (Şekil 7). 


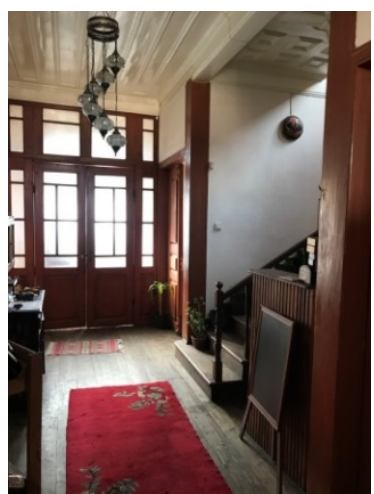

(a)

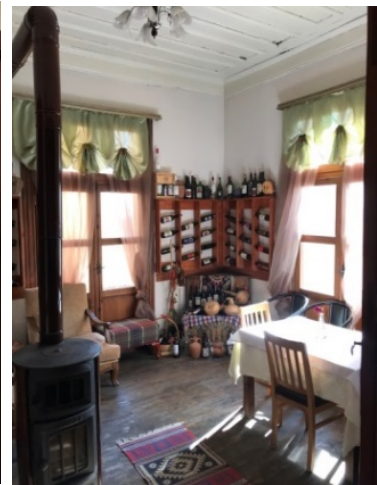

(b)

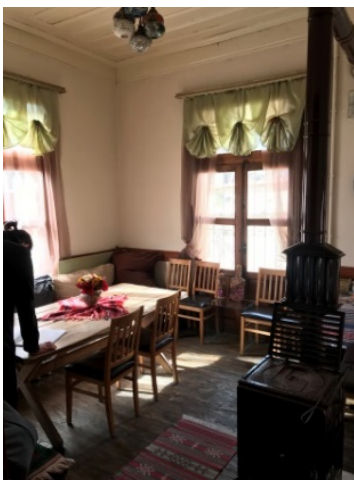

(c)

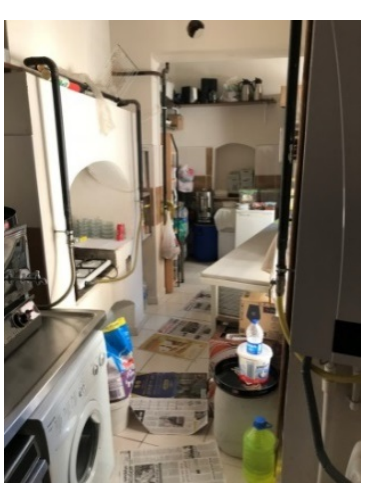

(d)

Şekil 7. Gusto Celepoğlu Konağı zemin kat iç mekân görünüşleri (Gülcan M. Yeler, 2021)

(a) Giriş mekânı (b) Sergileme alanları, antika eşyalar (c) Yemek yeme mekânı (d) Mutfak

Binanın özgün birinci katında (Tablo 1), merdivenden çıkıldıktan sonra bir kapı ile sofaya bağlantı sağlanmıştır. Sofa, bu katta daha da büyümüştür. Üç adet odaya ve servis mekânlarına sofadan bağlantı sağlanmaktadır. Sofa, zemin katta, merdivenin karşısında yer alan oda ve kilerin duvarlarının kaldırılması ve merdiven duvarının uzatılması ile büyütülmüştür. Zemin katta yer alan girişin üstü, bu katta balkon, rüzgârlığın üstü de her yerden bağlantısı olan bir ara mekân olarak düzenlenmiştir. Bu katta da, zemin kat ile aynı hizada yer alan kapı ve bir merdiven ile bahçeye bağlantı sağlanmıştır.

Yeniden işlevlendirme sonrasında, birinci katın mekân kurgusunda bir değişiklik olmamış, sadece burada yer alan sofa ve tüm odalar, oda konsepti anlayışıyla yemek yeme mekânına dönüştürülmüştür. Müdahale olarak ara mekânda odalara açılan kapılar kaldırılarak duvarla kapatıımış, sofaya geçişi sağlayan kapı da kaldırılarak sofa ile doğrudan mekânsal ve görsel ilişki sağlanmıştır (Şekil 8).

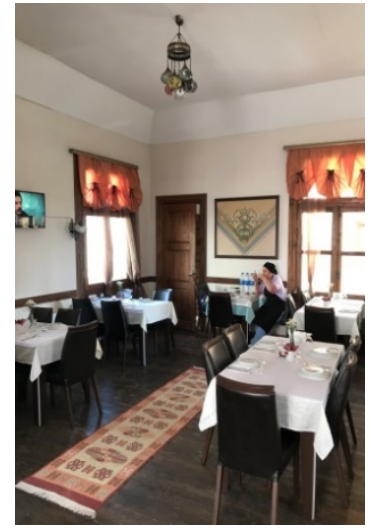

(a)

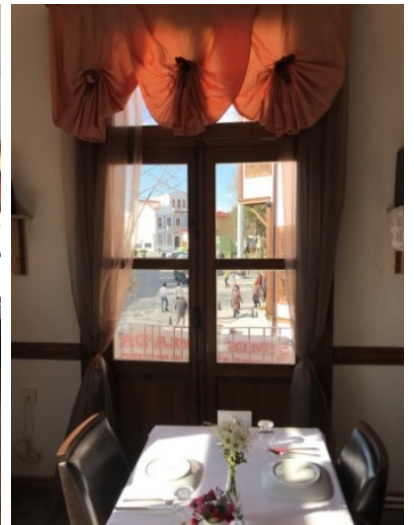

(b)

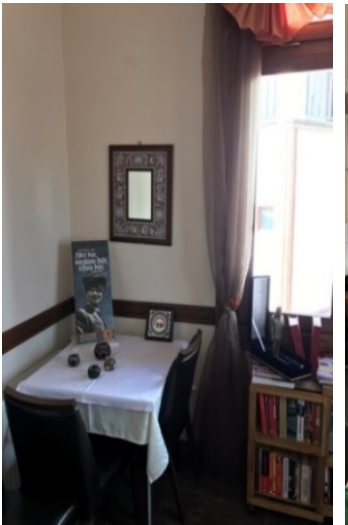

(c)

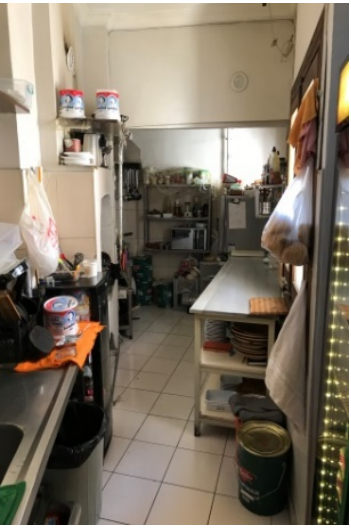

(d)

Şekil 8: Gusto Celepoğlu Konağı birinci kat iç mekân görünüşleri (Gülcan M. Yeler, 2021)

(a) (b) (c) Yemek yeme alanları (d) Mutfak

Arka bahçede, yeniden işlevlendirme sonrasında, mekâna gelen müşterilerin tüm mevsimlerde yemek yemeleri ve hoş vakit geçirebilmeleri için açık, yarı-açık ve kışın da kapalı mekân düzenlemeleri yapıımıştır (Şekil 9). 


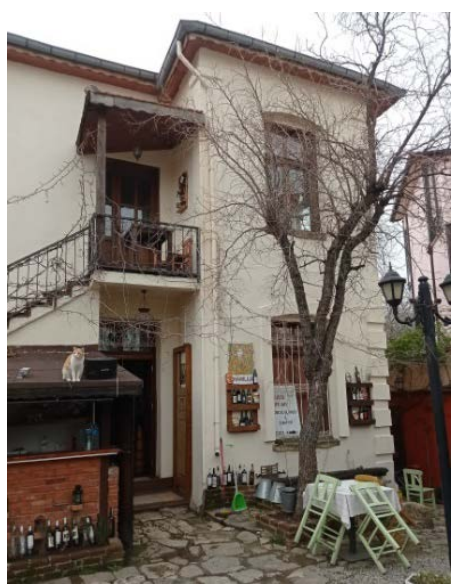

(a)

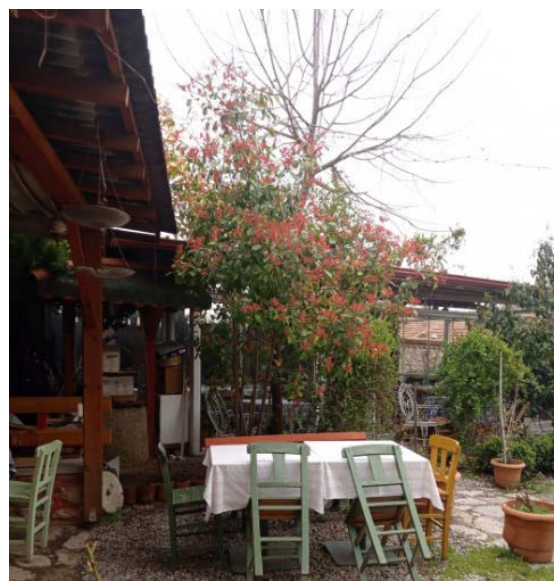

(b)

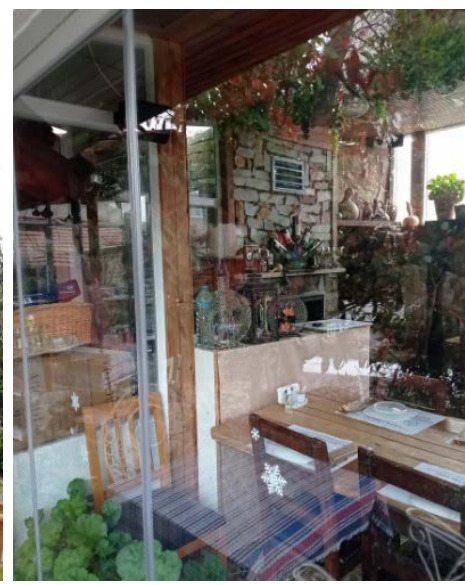

(c)

Şekil 9: Gusto Celepoğlu Konağı bahçe mekânından görünüşler (Gülcan M. Yeler, 2021)

(a) Binadan bahçeye çıkış ve servis alanı (b) Açık ve yarı-açık oturma mekânları (c) Camekânlı oturma mekânı

\subsection{Papazın Evi Bistro Cafe\&Bar Mekân Analizleri}

Kâgir sisteminde inşa edilen konut, bodrum ve zemin kattan oluşmaktadır. Bodrum katta geçmişte olduğu gibi mahzen ve bar konsepti, diğer katta ise alakart ve bütünleşik oda konseptine göre hizmet vermek üzere restoran olarak düzenlenmişlerdir (Tablo 2). Bahçeye giriş, Yayla Caddesi üzerinden, doğu cephesinden, yüksek taş duvarlı bahçe duvarında yer alan ahşap kapı ile sağlanmıştır. Bahçe kapısı ile aynı aks üzerinde konumlanan bina girişinde, dokuz basamaklı düz bir merdiven vardır (Şekil 4, Şekil 5).

Binanın özgün bodrum katının (Tablo 2), Gusto Celepoğlu Konağı'nda olduğu gibi Rumlar zamanında şaraphane/mahzen, Osmanlılar zamanında ve sonrasında da tahıl ambarı olarak kullanıldığı düşünülmektedir. Tek bir büyük mekândan oluşan bodrum kata giriş güney cepheden, bahçe kotundan inilen dört taş basamakla sağlanmıştır. Tuğla hatıllı kalın taş duvarlarla çevrili bu mekânda yer alan taş ayaklar üzerine oturtulan yedi adet ahşap dikme, zemin kat ahşap döşemesini taşımaktadır. Mekânın tavanı yüksek tutulmuştur. Yeniden işlevlendirme ile bodrum kat, canlı müzik dinletilerinin yapıldığı mahzen ve bara dönüştürülmüştür (Şekil 10). Bodrum katta, giriş merdivenleri yeniden düzenlenerek girişin solunda, batı cephesindeki çıkıntılı bölüme bara ait servis bankosu yerleştirilmiş, girişin tam karşısında da canlı müzik için sahne alanı yaratımıştır. Mekânda yer alan ahşap masa ve sandalyeler, dikmeler arasına belirli bir düzende yerleştirilmiştir (Şekil 10).

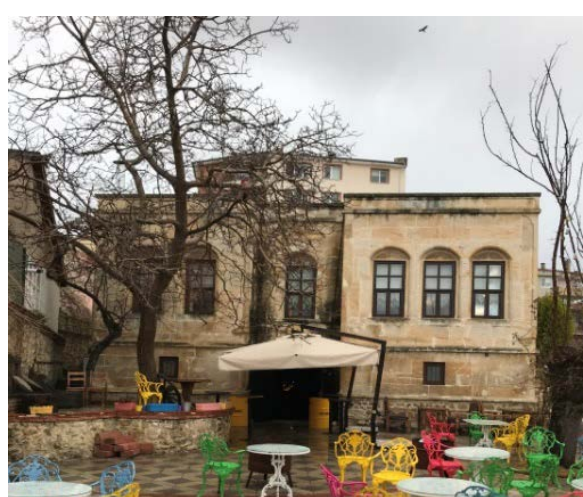

(a)

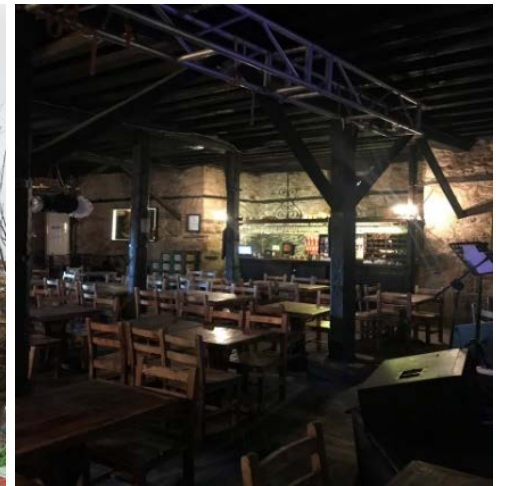

(b)

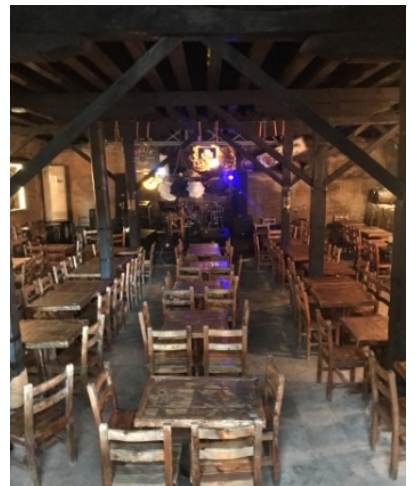

(c)

Şekil 10: Papazın Evi Bistro Cafe\&Bar bodrum kat girişi ve iç mekân görünüşleri

(Gülcan M. Yeler, 2021)

(a) Bodrum kat girişi (b) Bar mekânı ve oturma elemanları (c) Sahne alanı ve oturma elemanları 
Tablo 2: Papazın Evi Bistro Cafe\&Bar mekân analizleri (Gülcan M. Yeler, 2021)
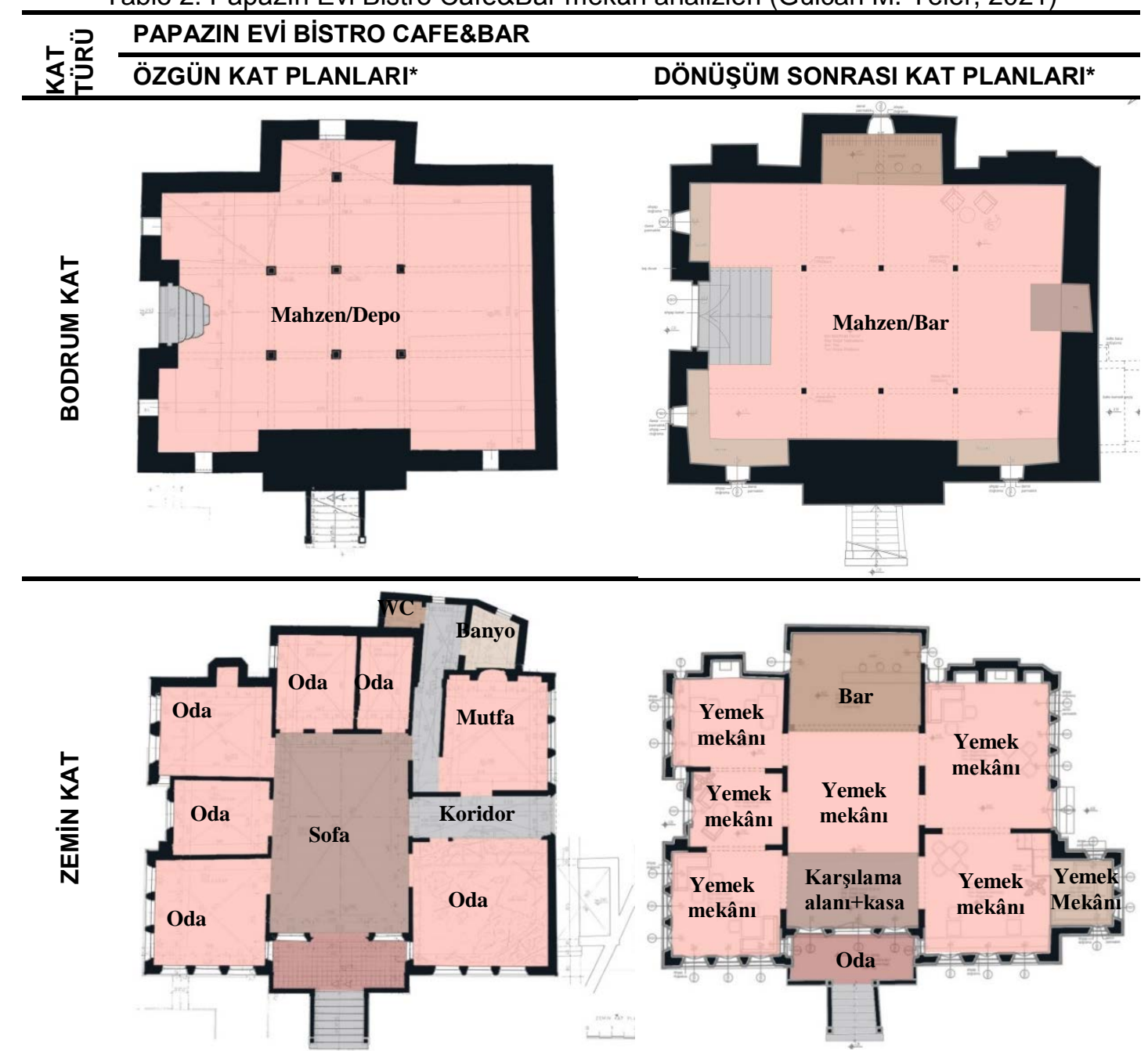

*Papazın Evi Bistro Cafe\&Bar'a ait mekân analizlerinde özgün işlevlerin gösterildiği kat planlarının oluşturulmasında Saatçi ve Uluengin yürütücülüğünde Mimar Sinan Güzel Sanatlar Üniversitesi, Meslek Yüksekokulu, Restorasyon Programı kapsamında yapılan çalışmalardan yararlanılmıştır. Dönüşüm sonrası kat planları Anfora Mimarlık tarafından yapılan restorasyon projesinden, yeni işlevler ve değişimler ise alan çalışması ile yazar tarafından yerinde tespit edilmiştir.

Yapının özgün zemin katında, sahanlıklı bir merdiven ile öncelikle sofaya ulaşılmaktadır. Farklı boyutlarda düzenlenmiş tüm odalara bağlantı sofadan sağlanmıştır. Mutfak, iki yönden sofa ile bağlantılı dar koridorlarla çevrelenmiştir ve bu koridorlardan mekâna girişler vardır. Binanın batı cephesinde, mutfağın solundaki koridordan ulaşılan tuvalet ve banyo mekânları konumlandırılmıştır. Mutfak ve karşısındaki odada ocağa yer verilmiştir. Yeniden işlevlendirme ile sofa kapalı bir orta mekândan daha açık bir karşılama, yemek yeme ve bar işlevlerini karşılayan çok işlevli bir mekâna dönüşmüştür. Girişin hemen sağında kasa/ödeme alanına yer verilmiştir. Girişin tam karşısındaki odalar, duvarları kaldırılarak açık bar olarak, diğer odalar da yemek yeme mekânı olarak kullanılmışlardır. Girişin sağındaki ilk odanın içinde, binaya eklenen oda, rölöve planında görülmeyen ancak özgün durumda varlığı bilinen merdivenler ile kot farkı yaratılarak daha yüksekte sergi ve yemek yeme mekânına dönüştürülmüştür. Sofadan odalara açılan kapılar kaldırılmış, odalar arasında kalan duvarlarda da boşluklar yaratılarak tüm mekânların geçişli olması sağlanmıştır. Mutfak ve tuvalet işlevleri, iç mekândan dışarıya alınmıştır. Yemek hazırlama ve servis hizmetleri, yenileme sürecinde, işletme sahibi tarafından satın alınan yan parselde yer alan iki katlı binanın mutfağa dönüştürülmesiyle sağlanmıştır. Tuvalet ve lavabo 
mekânları tamamen kaldırılmıştır, arka bahçede ayrı olarak yeniden düzenlenmiştir (Şekil 11).

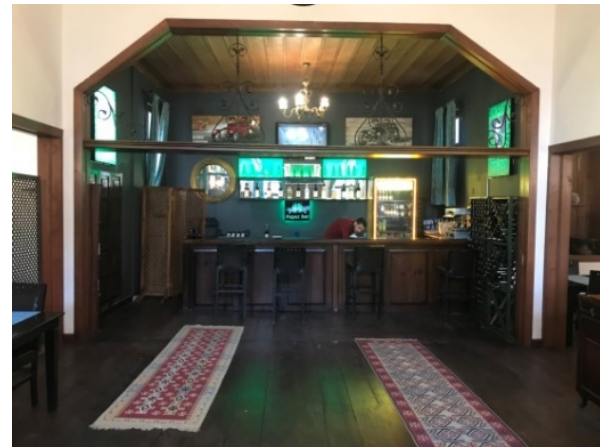

(a)

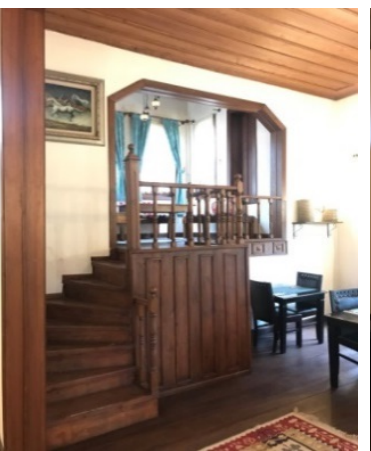

(b)

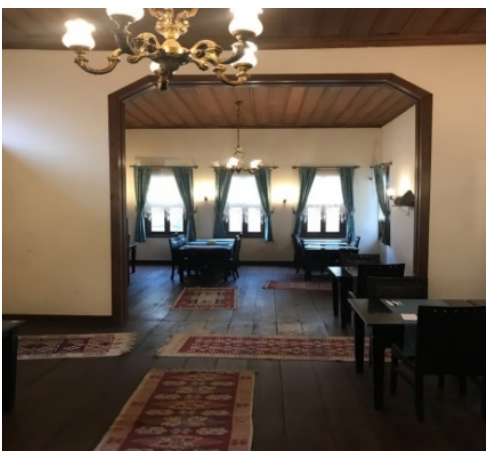

(c)

Şekil 11: Papazın Evi Bistro Cafe\&Bar zemin kat iç mekân görünüşleri (Gülcan M. Yeler, 2021)

(a) Bar mekânı (b) Oda içinde yükseltilmiş yemek yeme ve sergi mekânı (c) Yemek yeme mekânı

Ön bahçe, yeniden işlevlendirme sürecinde, yan parselin eklenmesiyle genişlemiştir. Mekâna gelen müşterilerin bahar ve yaz aylarında dışarıda yemek yemeleri, hoş vakit geçirebilmelerini sağlayacak şekilde düzenlenmiştir. Duvarlara sabitlenmiş açılır kapanır gölgelendirme elemanları ile gerektiğinde yarı açık alanlar oluşturularak koruma sağlanmıştır. Mutfak olarak kullanılan binanın önünde yarı-açık servis bankosu düzenlenmiştir. Arka bahçede tuvalet ve lavabo mekânlarına yer verilmiştir (Şekil 12).

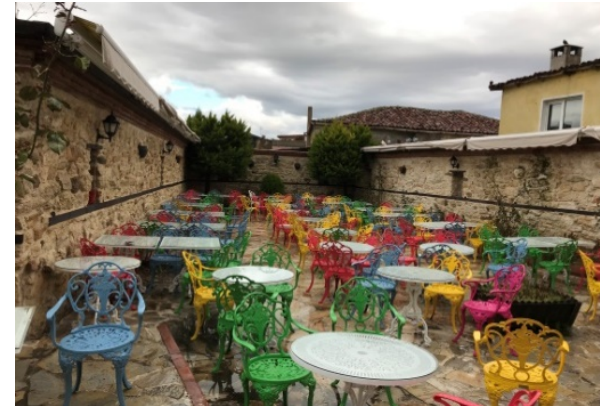

(a)

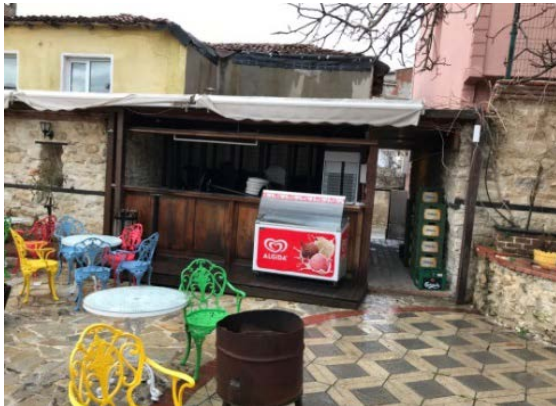

(b)

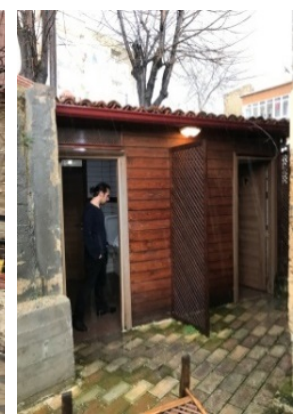

(c)

Şekil 12: Papazın Evi Bistro Cafe\&Bar bahçe mekânından görünüşler (Gülcan M. Yeler, 2021)

(a) Yan bahçe ve oturma elemanları (b) Servis bankosu (c) Tuvalet ve lavabolar

\section{Değerlendirme}

Günümüzde geleneksel konutların yeniden işlevlendirilmeleri sürecinde, kafe veya restorana dönüştürülmeleri son dönemlerde sıklıkla tercih edilen bir yöntem olmaktadır. Nitelikli bir yapının geleceğe aktarılmasında Çelebi Karakök (2017, s. 86), öncelikle o yapının özgünlüğünün korunmasının önemli olduğunu, yenileme çalışmalarının da bu amaç doğrultusunda yapılara en az müdahale ederek onarım ve sağlamlaştırımalarının yapılmasının gerekli olduğunu vurgulamaktadır. Bu kapsamda, geleneksel yaşam tarzına göre az sayıda kullanıcıya göre belirli boyutlarda tasarlanan bir konutun, kalabalık ve birbiri ile ilişkisi olmayan kullanıcıya hitap eden kamusal mekânlara dönüştürülmesi sürecinde özgünlüğün korunması önemli bir konu olmaktadır. Dinç Kalaycı ve Utku (2016, s. 357)'nun da belirttiği gibi, bir konutun kafeye dönüşümünde mekânların hangi kullanıcılara hitap ettiği, ne tür olanaklar sunduğu, mekânsal açıdan yeni işlevin konuta uygun olup olmadığı, gereksinimlerin değişimine bağlı olarak eylemlerin nasıl karşılanacağı, özel, yarı-özel ve kamusal mekânların nasıl 
kurgulanacağı ve yeni işlevin çevreye etkileri ve kazanımlarının ne olacağı gibi pek çok sorunun cevaplanması gerekmektedir. Bu kapsamda, çalışmanın bu bölümünde, sözü edilen sorulara açıklık getirmek, eski ve yeni işlev arasındaki uyum durumunu tespit etmek amacıyla çalışmaya konu olan iki bina üzerine değerlendirmeler yapılmaktadır. Değerlendirmeler mekânsal ve çevresel özellikler olmak üzere iki başlık altında ele alınmaktadır.

Mekânsal özellikler bakımından değerlendirmelerde; işlevsel dönüşüm yapılan bir yapıda yeni işlev doğrultusunda şekillenen mekânsal düzenin, mevcut düzen ile üst üste çakıştırılması ile mekânın özgün karakterinin ne ölçüde yansıtıldığına (Selçuk, 2006 , s. 1) dikkat edilmektedir. Değerlendirmelerde, yeni işlevin gerektirdiği mekân türleri olan karşılama alanı/lobi, yemek alanı, bar, kasa alanı, ofis, servis girişi, mutfak, servis alanları, personel alanları, tuvalet, depo gibi mekânlara göre yorumlar yapılmaktadır. Tüz (2017, s. 138)'ünde belirttiği gibi iyi bir işlev şemasının kalitesi, işletmenin ekonomik verimliliği açısından önemli bir fark yaratırken, iyi çözülmemiş bir işlev şeması çatışma noktaları, servis süresinde artış, koku taşmaları ve diğer konfor koşullarının sağlanamamasına sebep olabilir ve ilk anda elde edilen kazanımların kaybına yol açabilmektedir. Bu yönleriyle iki binanın yeniden işlevlendirilen mekânları; büyüklük, biçim, yükseklik, mekânlar arası ilişki, dolaşım şeması, kapasite, esneklik, donatı kurgusu (Yaldız ve Asatekin, 2016, s. 171; İslamoğlu, 2018, s. 514) gibi konular üzerinden değerlendirilmektedir.

Çevresel özellikler bakımından değerlendirmelerde; binaların çevresi ile bir bütün olduğu düşünülerek yeni işlevin bulunduğu çevre özelikleri bakımından ne kadar uyumlu olduğu, çevre içerisinde intiyaçları ne ölçüde karşıladığı, çevreye fiziksel, sosyo-kültürel ve ekonomik açılardan ne tür etkileri olduğu dikkate alınmaktadır. Türker (2019)'in de belirttiği gibi bölgede yaşayan insanların talepleri ya da sosyo-ekonomik durumları göz önüne alınmadan verilen yeni işlev kararı, dönüştürülen binanın talep görmeyerek yeniden terk edilmesine sebep olabilmektedir. Bu yönleriyle yeniden işlevlendirilen iki bina; çevrede bir tanımlama ve tarif etme aracı olması, röper noktası oluşturması, kent için bir merkez, buluşma noktası özelliği taşıması, yaya ve taşıt erişilebilirliği, otopark imkânı, çevrede yer alan doku ile görsel bütünleşmesi/uyumu, yeşil alan kullanımı, dış mekân ilişkisi gibi konular üzerinden değerlendirilmektedir (Yaldız ve Asatekin, 2016, s. 169; İslamoğlu, 2018, s. 514).

Değerlendirmelerde, yerinde yapılan gözlem ve karşılaştırmalı mekân analizlerine ek olarak restoran ve kafe çalışanları ile sözlü görüşmelere de yer verilerek, ele alınan konuların farklı bakış açıları ile tartışılması sağlanmaktadır.

\subsection{Mekânsal Özellikler Bakımından Değerlendirme}

Genel olarak yerinde yapılan gözlem, karşılaştırmalı mekân analizleri ve sözlü görüşmelerden elde edilen veriler doğrultusunda, her iki konutun işlevsel dönüşümleri değerlendirildiğinde, konut mekânlarının özgün hacimsel ve mekânsal özellikleri göz önünde bulundurularak geliştirilen tasarım fikirleri ile eski ve yeni işlev arasındaki uyumun büyük ölçüde sağlandığı gözlenmiştir. Binaların mekân kurgusunda özgün plan şeması korunmuş, yeni programın intiyaçlarını karşılayacak işlevsel dönüşüm (Tablo 3) ve tefrişlerle yapılan değişikliklerin ötesinde, mimari karakteri bozmayacak az sayıda müdahalelerde bulunulmuştur. 
İki Rum Konutunun İşlevsel Dönüşümünün Mekânsal ve Çevresel Bağlamda Değerlendirilmesi: Kırklareli Yayla Mahallesi Örneği An Evaluation of the Functional Transformation of Two Greek Houses in Spatial and Environmental Context: The Case of Kırklareli Yayla District

Tablo 3: Özgün ve yeni işlevlerin karşılaştırılması (Gülcan M. Yeler, 2021)

\begin{tabular}{|c|c|c|c|c|}
\hline \multirow[b]{2}{*}{ KAT TÜRÜ } & \multicolumn{2}{|c|}{ GUSTO CELEPOĞLU KONAĞI } & \multicolumn{2}{|c|}{ PAPAZIN EVI BISTRO CAFE\&BAR } \\
\hline & Özgün İşlev & Yeni İşlev & Özgün İşlev & Yeni İşlev \\
\hline Bodrum Kat & $\begin{array}{l}\text { Mahzen } \\
\text { Depo }\end{array}$ & $\begin{array}{l}\text { Mahzen } \\
\text { Bar }\end{array}$ & $\begin{array}{l}\text { Mahzen } \\
\text { Depo }\end{array}$ & $\begin{array}{l}\text { Mahzen } \\
\text { Bar }\end{array}$ \\
\hline Zemin Kat & $\begin{array}{l}\text { Yaşam alanı } \\
\text { Kiler/Depo }\end{array}$ & $\begin{array}{l}\text { Karşılama+kasa } \\
\text { /Ödeme alanı } \\
\text { Sergi alanı } \\
\text { Yemek yeme } \\
\text { mekânı }\end{array}$ & $\begin{array}{l}\text { Yaşam alanı } \\
\text { Mutfak } \\
\text { Tuvalet-Banyo }\end{array}$ & $\begin{array}{l}\text { Karşılama+kasa/öd } \\
\text { eme alanı } \\
\text { Yemek yeme } \\
\text { mekânı } \\
\text { Bar }\end{array}$ \\
\hline Birinci Kat & Yaşam alanı & $\begin{array}{l}\text { Yemek yeme } \\
\text { mekânı } \\
\text { Tuvalet } \\
\text { Personel Odası }\end{array}$ & - & - \\
\hline Ek Bina & $\begin{array}{l}\text { Mutfak } \\
\text { Tuvalet- } \\
\text { Banyo } \\
\end{array}$ & $\begin{array}{l}\text { Mutfak } \\
\text { Tuvalet } \\
\text { Kiler/Depo } \\
\end{array}$ & $\begin{array}{l}\text { Yaşam alanı } \\
\text { Mutfak } \\
\text { Tuvalet-Banyo }\end{array}$ & $\begin{array}{l}\text { Mutfak } \\
\text { Tuvalet } \\
\text { Kiler/Depo }\end{array}$ \\
\hline Bahçe & $\begin{array}{l}\text { Açık oturma } \\
\text { alanı }\end{array}$ & $\begin{array}{l}\text { Açık,yarı-açık } \\
\text { kapalı oturma } \\
\text { alanları }\end{array}$ & $\begin{array}{l}\text { Açık oturma } \\
\text { alanı }\end{array}$ & $\begin{array}{l}\text { Açı, yarı-açık } \\
\text { oturma alanı }\end{array}$ \\
\hline
\end{tabular}

Yeni işlevde, bodrum katta eski işlevlerin korunmasına özellikle dikkat edilmiş, bu yaklaşım yeni işlevde, eski dönemlerin yaşantısını yansıtmada ve her iki binanın konseptinin belirlenmesinde etkili olmuştur. Gusto Celepoğlu Konağı'nda, mekân bütünlüğünün sağlanması için bodrum katta muhdes olduğu düşünülen iç duvarlar kaldırımıştır. Böylece mekân ferahlatılmış, özgün ahşap taşıyıcılar da görünür kıınmıştır. Ancak, artırılmasına rağmen mekân yüksekliğinin $(2 \mathrm{~m})$ yeterli olmaması, mekânın basık hissedilmesine neden olmuştur (Şekil 6). Çalışanlar ise bu durumdan bir rahatsızlık duymadıklarını belirtmişlerdir. Papazın Evi Bistro Cafe\&Bar'da ise özgün açık mekân kurgusu ve kat yüksekliğinin $(3.50 \mathrm{~m})$ yeterli olması, mekânı oldukça ferah kılmıştır (Şekil 10).

Binaların diğer katlarında, odalardan oluşan parçalı mekân düzeni korunmuş; yaşama, yatma, yemek yeme gibi eylemlerin gerçekleştiği odalar ve sofa, restoran ve kafelerin oturma alanları gibi hizmet alanlarına dönüştürülmüştür. Binaların giriş mekânlarında yeni işlev gereği kasa-ödeme alanı oluşturulmuştur (Tablo 1). Gusto Celepoğlu Konağı'nda oda konsepti anlayışı olduğu gibi korunurken (Şekil 7), Papazın Evi Bistro Cafe\&Bar'da mekânlar arasında geçişi sağlayan kapılar ve bazı duvarlar kaldırılarak tüm oturma alanları arasında görsel süreklilik sağlanmıştır (Tablo 2) (Şekil 11). Restoran ve kafeler, esas işlevleri olan yemek yeme-içme dışında insanların dinlendikleri, eğlendikleri ve sosyalleştikleri mekânlar olarak kullanıldıkları düşünüldüğünde, odalarda ayrı olarak gerçekleştirilen eylemlerin sosyal iletişim, etkileşim ve birlikteliği olumsuz yönde etkileyeceği kanısı oluşmuştur. Ancak, Gusto Celepoğlu Konağı'nda daha baskın hissedilen bu durumun sözlü görüşmeler sonrasında tam tersine, olumsuz karşılanmadığı; kutlama yapma, sessiz ve sakin bir ortamda yemek yeme isteği gibi durumlarda özellikle tercih sebebi olabildiği belirtilmiştir.

Restoran tasarımlarında önemli olan bir konu; mutfağın mekân içinde yeri, mutfakta alan düzenlemesi ve mutfak ekipmanlarının seçimidir. Mutfak tasarımında temel amaç ise, mutfağın kullanımı ve yararlanılmasında işlevselliğin ön plana çıkarılmasıdır. İnsan gücünün azaltılması, çalışanların verimliliğini ve çalışma isteğini artırması, zamanın verimli kullanımı ve kaliteli bir yemek servisinin sağlanması bakımından işlevsellik 
önemlidir. Bu yönleriyle, yemek yenilecek mekânların mutfağa göre uzak ve başka bir katta olmaması da istenmektedir (Akın, 2015, s. 254). Gusto Celepoğlu Konağı'nda mutfağın, her katta yer almasına rağmen büyüklük ve düzen bakımından yetersiz olduğu düşünülmektedir. Papazın Evi Bistro Cafe\&Bar'da mutfağın dışarıda, ayrı bir binada, yemek yeme mekânlarından uzak olmasının çalışanların performansını ve kötü hava koşullarında servis kalitesini olumsuz yönde etkilediği gözlemlenmiştir. Çalışanlar ise bu konular hakkında bir sorun belirtmemişlerdir.

Restoran ve kafelerde yardımcı alanların kapsamında, müşteri ve çalışan tarafından kullanılmakta olan tuvaletler, yiyecek ve içecek için gerekli depolar, çalışanların hazırlık odaları, yönetim ofisi gibi mekânlar yer almaktadır. Tuvaletlerin kolayca ulaşılır olması en dikkat edilmesi gereken ilkedir. Tuvaletlerde erkek ve kadın olmak kaydıyla iki ayrı kısım yapılması gerekmektedir (Doğan Karakan, 2019, s. 18). Bu kapsamda, tuvalet ve lavabo mekânlarının Gusto Celepoğlu Konağı'nda içeride (Tablo 1), Papazın Evi Bistro Cafe\&Bar'da ise özgün kat planında olduğu yerden kaldırılarak arka bahçede düzenlendiği görülmektedir (Tablo 2, Şekil 12). Papazın Evi Bistro Cafe\&Bar'da tuvaletlerin, restoran ve mahzen katlarındaki müşterilerin ortak kullanımına imkân verecek şekilde dış mekânda çözümlenmesi, özellikle restoran mekânına ulaşım mesafesinin fazla olması nedeniyle, soğuk kış günlerinde müştreriler için sorunlara neden olacağı düşünülmektedir. Depo gibi birimler ise ek binalar da konumlandırılmıştır.

Konutların yeni işlevi, çalışanlar tarafından uygun görülmüştür. Eski işlevleri konusunda "Rum bir doktorun evi", "papaza ait bir ev" yorumları yapılmıştır. Mekânların dekorasyonunda, konutlardaki geçmişin yaşam biçimini yansıtan eşyalar ve resimlerin kullanılması, ayrıca, broşürlerde eski işlevlere ait bilgilendirmelerin yapılması geçmişin öğretilmesine, sürdürülebilirliğine katkı sağlamaktadır. Gusto Celepoğlu Konağı'nda sergileme yaklaşımı, konseptin çıkış noktasını oluşturmuş, tüm katlarda şarap ve yemek kültürü ile kent kimlik ve kültürünü yansıtan pek çok öğeye yer verilmiştir. Papazın Evi Bistro Cafe\&Bar'da yükseltilmiş mekânda yöresel bir dekorasyon yapılmıştır. Her iki binanın çalışanları, mekânları daha çok sıcak, otantik, doğal, rahat, ferah ve nezih gibi kavramlarla ifade etmişlerdir.

Restoran ve kafelerde dış mekânlar, en önemli ve en çok talep gören yerlerdir. Her iki binada yüksek bahçe duvarları ile çevrelenmiş olan bahçeler, yeni işlevde açık oturma alanlarına dönüştürülmüştür. Bu alanlar, yeme-içme ile birlikte müşterilerin rahatlama, sohbet etme, okuma, oturma ve müzik dinleme gibi farklı eylemlerinin de gerçekleşmesine olanak tanıyacak şekilde düzenlenmişlerdir. Müşterilerin konforunu sağlamak için yağmur, rüzgâr ve güneş gibi olumsuz hava koşullarından korumak için yarı-açık mekânların yaratılması gerekli olmuştur. Gusto Celepoğlu Konağı'nda yarıaçık mekân kullanımı yoğun olmakla birlikte yakın zamanda camdan bir kış bahçesi de oluşturulmuştur. Çiçekler ve ağaçlar gibi peyzaj öğelerine yer verilmiştir. Bahçede kullanılan donatı elemanları ve malzemeler mekânın eski dokusuna uygundur (Şekil 9). Papazın Evi Bistro Cafe\&Bar'da ise ön bahçeye eklenen yan bahçe ile birlikte daha çok açık mekan kullanımı söz konusudur. Gerektiğinde açılır kapanır gölgelendirme elemanları ile koruma sağlanabilmektedir. Ön bahçede mevcut ağaçlar korunmuş, ek kısımda az sayıda saksı çiçeğine yer verilmiştir. Masa ve sandalyelerde kullanılan renkli metal ferforje malzemenin, binanın özgün dokusu ve diğer tefriş malzemeleri ile uyumlu olmadığı gözlenmiştir. Her iki bahçede de yarı-açık servis bankosuna yer verilmiştir (Şekil 12).

Konutların yeni kullanımlarında kapalı ve açık mekânlar; düğün, toplantı, davet ve özel kutlamalar gibi farklı etkinlikler için de kullanılabilmektedir. Her iki binada da tespit 
edilen en önemli eksiklik; bina girişlerinde, katlar arasında, ıslak hacimlerde ve bahçe mekânlarında herkes için tasarım ilkelerini dikkate alan çözümlerin geliştirilememiş olmasıdır.

\section{2. Çevresel Özellikler Bakımından Değerlendirme}

Genel olarak değerlendirildiğinde, konutların yeni işlevinin restoran ve kafe olarak belirlenmesinde "tarihi olan ve bir dönemin yaşantısını sergileyen konutları çağdaş yaşam içerisine katarak yapının sürekliliğini sağlamak" olan ana fikir ile örtüştüğü görülmektedir. Ayrıca, mahalle/kent sakinlerinin ihtiyaçlarının, fiziksel, sosyo-kültürel ve ekonomik gerekliliklerinin de dikkate alındığı tespit edilmiştir.

Gusto Celepoğlu Konağı ve Papazın Evi Bistro Cafe\&Bar çok özel bir çevrede yer almaktadır. Mahallenin ana aksı olan Yayla Caddesi üzerinde konumlanan ve mahallenin merkezini oluşturan Yayla Meydanı ve parkına da ulaşım açısından yakın mesafelerde konumlanan binalar (Şekil 1,4) yeni işlevleri ile birlikte bulundukları çevre içinde bir buluşma ve odak noktası oluşturmuşlardır. Bu oluşumda, meydanın tarihsel özelliği ve mahallede uygulanan projeler etkili olmuştur. Mübadele öncesinde çevresinde yer alan önemli yapıları barındırması, ayrıca toplantı, kutlama ve miting gibi önemli faaliyetlerin gerçekleştiği Yayla Meydanı, 2013 yılında Kırklareli Belediyesi tarafından "Tarih, Tarih Olmasın Yayla Mahallesi Sokak Sağlıklaştırma ve Kentsel Tasarım Hamlesi" adı altında yürütülen proje ve Kırklareli İı Özel İdaresi, İ Kültür ve Turizm Müdürlüğünün katkıları ile mahalle, eski canlıı̆ını tekrar kazanmıştır. Üretilen proje kapsamında mahallede birçok cadde ile sokak yenilenmiş, Yayla Parkı'nda çevre düzenlemeleri yapılmıştır. Terk edilen konutlar, yenileme sonrasında bir kaçı özgün işlevlerini korurken, sözü edilen restoran ve kafelerin haricinde butik otel, müze, idari ofis, okul gibi yeni işlevler kazandırılarak geleneksel konutlar yaşatılmaya çalışılmıştır. Mustafa Kemal Atatürk'ün Selanik'te yaşadığı evin aynısı, Gusto Celepoğlu Konağı'nın yanına yapılmıştır (Şekil 2, 3). Bir cazibe noktasına dönüşen meydan ve çevresinde, yılın belirli günlerinde düzenlenen Uluslararası Yayla Bolluk, Bereket, Hasat ve Bağbozumu Şenliği ile Yayla Meydanı, farklı kültürel aktivitelerle zenginleştirilerek mahalle sakinleri ve halk tarafından daha çok tercih edilen bir mekân olmuştur.

Binalara, konumları gereği, yaya ve araç ile ulaşım oldukça kolaydır. Ancak, binaların kendilerine ait otoparkları bulunmamaktadır. Gusto Celepoğlu Konağı meydana daha yakın olması nedeniyle daha avantajlı konumdadır. Gerektiğinde, meydandaki otoparklardan yararlanabilmektedir. Papazın Evi Bistro Cafe\&Bar ise meydana daha uzak olması nedeniyle yakın çevresindeki sokaklarla bu intiyacı karşılamaktadır. Yaz mevsiminde meydan ve çevresinde canlılık arttığı için mevcut otopark, intiyacı karşılayamamaktadır.

Konutların yenilenmesi sürecinde her iki binanın da iç mekan ve cephelerinde özgünlüğün korunması, iç mekanda nostaljik eşyaların kullanılması; binaların ifade ettiği simgesel, tarihi, kültürel ve mimari kimlik değerlerinin sürdürülebilirliğini sağlayarak kullanıcıların belleğinde yer edinmelerini sağlamada ve çevreye kattığı anlamı zenginleştirmede etkili olmuştur.

Yerel kimlik arayışında, son dönemlerde, yemekler ve yemek şekli kültürümüzün ve yaşam biçimimizin temel öğelerinden olduğu için yiyecekler de önemli bir faktör haline gelmiştir. Gastronomiye olan talebin arttığı günümüzde, kültürel değerlerden yemeiçme unsurlarını en iyi şekilde tanıtmak ve bunu ekonomik bir kazanca dönüştürerek, bölgesel kalkınmaya katkı sunmak oldukça önem kazanmaktadır. Kültürel mirasın önemli bir parçası olan gastronomi turizmi ile ziyaretçilere yeni kültürler, kokular, tatlar ve lezzetler sunarak öğrenme fırsatı sunulmakta (Çelik, 2018, s. 43), yerel halkın 
tüketim alışkanlıklarının ve mutfaklarda kullanılan yerel kültürü yansıtan araç-gereçlerin tanıtımasına imkân tanınmakta; pazarlama, imaj ve reklam açısından önemli rekabet avantajı yaratılmaktadır (Uyar, 2021, s. 239). Bu yönleri ile her iki restoranın konseptinin belirlenmesinde yeme-içme unsurlarının etkili olduğu saptanmıştır. Özellikle yeni işleve bağlı olarak tasarımlarda geçmişte şarap kullanımına vurgu yapılarak bodrum katlar mahzene dönüştürülmüştür. Gusto Celepoğlu Konağı'nın işletmecisinin Balkan mutfağı ve Kırklareli yöre mutfağı üzerine deneyimlerinin olması nedeniyle restoranda da yöresel yemeklerin sunulması, gastronomi turizmine katkı sağlamaktadır. Şarap ve yemek kültürüne ait eşyalar mekânlarda sergilenerek bilgi edinilmekte, böylece gelecek kuşaklara kültürel miras aktarılmaktadır. Papazın Evi Bistro Cafe\&Bar'da da Kırklareli mutfağına özgü yemekler sunulmaktadır.

Kırklareli Yunanistan ve Bulgaristan'a yakınlığı ve kültürel geçmişi ile bu ülkelerden gelen turistler için uğrak yeri olmakta, Yayla Mahallesi sözü edilen özellikleri ile kentte çekim noktası oluşturmaktadır. Dolayısıyla, Gusto Celepoğlu Konağı ve Papazın Evi Bistro Cafe\&Bar'ın turistler, yerli halk ve özellikle de genç nesil tarafından tercih edilme oranı artmıştır. Binanın yeni işlevi, kullanıcılarına ekonomik fayda sağladığı gibi gençlere iş imkânı da sunmaktadır. Çalışanların çoğu üniversite öğrencisidir.

Yerinde yapılan tespitlere ek olarak yeni işlevin çevresel özellikler bakımından mahalleye/kente kazanımları sorgulandığında, çalışanlar yukarıda dile getirilen konuları destekler nitelikte binalar hakkında şu cevapları vermişlerdir:

- Yerli halk, gençler, yerli ve yabancı turistler için tercih edilen mekânlar olması,

- Sakin, huzurlu bir ortam sunması,

- Aile ile gelinecek nezih ortamlar sunması,

- Turist çekmesi ve turizmi geliştirmesi,

- Mahalleye canlılık katması, cazibe merkezi yaratması,

- Mahallenin ve kentin tanınırlığını artırması,

- Tarihi yaşatması, geçmişi öğretmesi, insanların bilgi düzeyini artırması,

- Yöresel yemek ve şarap kültürünü tanıtması,

- Tarihi ve kültürel değer yaratması, yerel kimlik yaratması,

- Öğrencilere ve yerli halka iş imkânı yaratması ve ekonomik kazanç yaratması.

Bu cevaplar, seçilen yeni işlevlerin mahallenin özelliklerinin dikkate alınarak belirlendiğini ortaya koymaktadır.

\section{Sonuç}

Geçmişi tüm değerleriyle yansıtan, geçmiş-bugün-gelecek arasında bağlantı kuran ve sürdürülebilirliği sağlayan geleneksel konutlar, Yayla Mahallesinin kimliğinin oluşmasında katkı sağlamışlardır. Mahallede ve kentin genelinde korunmaya değer daha pek çok konut mevcuttur. Çalışmaya konu olan konuttan restoran ve kafeye dönüşümü gerçekleştirilen iki binanın süreçleri mekânsal ve çevresel bağlamda değerlendirildiğinde eski ve yeni işlev arasında uyumun büyük ölçüde sağlandığı görülmektedir.

Bu kapsamda, mahallede ve kent genelinde diğer binalarda yapılacak yeniden işlevlendirmelerde, başarılı sonuçlara ulaşma noktasında, yeni işleve karar vermeden önce kapsamlı araştırmaların yapılması gerekmektedir. Özellikle geçmişin yaşatılması konusunda konutlar hakkında tarihi belgelere dayanan araştırmaların yapılması, eski 
dönemlere tanıklık eden yaşlı kişilerle görüşülmesi tarihsel-sosyo-kültürel verilerin ortaya konması bakımından çok önemlidir. Eski ve yeni projeler üzerinden ve yerinde tespit çalışmaları ile ortaya konan mimari belgeleme çalışmaları, özgünlüğün yansıtılması, zaman içerisinde yaşanan değişim ve dönüşümlerin belirlenmesi ve bunların altında yatan sebeplerin ortaya konması bakımından çok değerlidir. Yeniden işlevlendirme sürecinde mahalle/kent sakinlerinin güncel ihtiyaçlarının, fiziksel, sosyokültürel ve ekonomik gerekliliklerinin de dikkate alınmasıyla konutların çevrelerine çok yönlü değerler kazandıracağı öngörüsüyle, mahalle sakinleri ve halk ile ayrıca mekânı kullanacaklar ile de sözlü görüşmeler, anketler yapılması konutların sürdürülebilirliğinin sağlanması bakımından gereklidir.

Sözü edilen araştırma yöntemleri doğrultusunda çağdaş bir yaklaşımla yapılacak yeniden işlevlendirmenin, geleneksel konutların bulunduğu çevrede yaşayan bir kültürel varlık olarak günümüz ve geleceğe aktarımında etkili olacağı açıkça görülmektedir. Bu bağlamda, çalışmaya konu olan konuttan restorana dönüştürülmüş iki bina; çevrelerinde bir odak ve çekim noktası oluşturmaları, mahalleyi bir cazibe merkezine dönüştürmeleri, cephe ve mekân kurgusundaki özgünlüğün korunarak mimari kimliğin sürdürülebilmesine, böylece tarihi yaşatarak geçmişin öğrenilmesine katkı sağlamaları, yemek kültürünün tanıtılarak yöresel değerlerin ön plana çıkarılmasına destek olmaları bakımından diğer yeniden işlevlendirme uygulamalarına örnek oluşturabileceği düşünülmektedir.

TEŞEKKÜR: Bu çalışmaya, alan çalışması ve çizimlerin düzenlenmesi sürecinde katkı sağlayan Mimar Ahmet Ertaş'a teşekkür ederim.

\section{Kaynaklar}

Ahunbay, Zeynep., Tarihi Çevre Koruma ve Restorasyon, İkinci baskı, İstanbul, Türkiye: Yem Yayın, 1999.

Akın, Emine, Saka.; Özen, Hamiyet, "Tarihi Yapılarda Yeniden Kullanım Sorunları, Tokat Meydan ve Sulu Sokak", Sosyal Bilimler Araştırmaları Dergisi. I, 2013, s. 23-48.

Akın, Galip; Gültekin, Timur, "Günümüz Restoran Tasarımında Kriterler," Süleyman Demirel Üniversitesi Mühendislik Bilimleri ve Tasarım Dergisi, c. 3, s. 3, 2015, s. 251258.

Apa Kurtişoğlu, Gülay, "Kırklareli Geleneksel Evlerinde Cephe Düzenlemesi," Tarihin Peşinde-Uluslararası Tarih ve Sosyal Araştırmalar Dergisi, s.12, 2014, s. 187-219.

Apay, Ahmet Celal; Önür, Özlem Özkan; Bideci, Alper, "Taraklı'daki Sivil Mimarlık Örnekleri ile Ali Pektaş Evi'nin Restorasyonu", Düzce Üniversitesi Bilim ve Teknoloji Dergisi, c. 7, sayı. 1, 2019, s. 160-179.

Aslan, Fürüzan; Ateş, Oğuz; Menteş, Yaşar, "Kentsel mekân ve morfoloji ilişkisi: Kırklareli İli Yayla Mahallesi örneği," Kırklareli Üniversitesi Mühendislik ve Fen Bilimleri Dergisi, c. 6, s. 2, 2020, s. 165-184.

Aydın, Dicle; Yaldız, Esra, "Yeniden Kullanıma Adaptasyonda Bina Performansının Kullanıcılar Üzerinden Değerlendirilmesi," Ortadoğu Teknik Üniversitesi Mimarlık Fakültesi Dergisi, c. 27, s. 1, 2010, s. 1-22. 
Behar, C., Osmanlı İmparatorluğu ve Türkiye'nin Nüfusu (1500-1927), Tarihi İstatistikler Dizisi, Cilt 2, Ankara: Devlet İstatistik Enstitüsü Yayınları, 1996.

Broşür, Gusto Celepoğlu Konağı Broşürü, 2021.

Çelebi Karakök, Elif, "Bir Geleneksel Türk Evini Geleceğe Aktarmak: Erdoğan Kalay Evi ve Koruma Önerileri," Osmanlı Mirası Araştırmaları Dergisi, c. 4, s.10, 2017, s. 85110.

Çelik, Sedat, "Şırnak İlinin Gastronomi Turizmi Potansiyeli," Uluslararası Güncel Turizm Araştırmaları Dergisi, c. 2, s. 2, 2018, s. 41-51.

Dinç Kalaycı, Pınar; Utku, Tuğçe, "Konuttan Dönüştürülmüş Kafelerde Kullanıcı Memnuniyeti: Konya Kent Merkezinden Bir Örneklem," Megaron, c. 11, s. 3, 2016, s. 344-358.

Doğan Karakan, Canan, Gaziantep Yeme l̇çme Mekânlarının Tasarımında Yeni Eğilimler, Yüksek Lisans Tezi, Mimarlık Bölümü, Hasan Kalyoncu Üniversitesi, Gaziantep, Türkiye, 2019.

Doğruöz, V., Türkan, "Kırklareli Tarihine Işık Tutacak Bir Eser: Türkiye'nin Sıhhi-i İçtimai Coğrafyası Kırklareli Vilayeti”, History Stedies, Volume:3/1, 2011, s. 275-284.

Doğruöz, V. Türkan; Dökmeci, Volkan. Çiftçi, Alifer, “Kırkkilise Sancağı'nın Tarihi ve Coğrafî Açıdan Tasviri (Perigrafi İstoriogeografiki Tis Eparhias Ton Saranta Ekklision) Adlı Eser Tercümesinin Kırklareli Tarihi Açısından Yorumlanması," ABAD, 3(6), s. 71105.

Eres, Zeynep, "Kırklareli'nin Mimarlık Kültürü Üzerine Araştırmalar," Arkeoloji ve Sanat, s. 152,2016 , s. $201-216$.

Eyüboğlu Erşen, Aysun., "Tarihi Kentlerin Korunmasında, Koruma Amaçlı İmar Planlarının Getirdiği Sınırlamalar ve Uygulama Sorunlarının Kırklareli Örneğinde İrdelenmesi," 9. Uluslararası Sinan Sempozyumu, Edirne, Türkiye, 2015, s.221-228.

Güneş Çiçek, Leyla, Kentsel Sit Alanlarında Alan Yönetimi-Sille (Konya) Örneği, Yüksek Lisans Tezi, Şehir ve Bölge Planlama Bölümü, Gazi Üniversitesi, Ankara, Türkiye, 2010.

Gündoğdu, H. Meltem ve Uğuz, Mustafa, “İnsan-Mekân Etkileşimi Bağlamında Kırklareli Merkez Yayla ve Vilayet Meydanları Kullanılabilirlik Durumunun Araştırılması," Kent Akademisi Dergisi, c. 13, s. 2, 2020, s. 315-337.

İslamoğlu, Özge, "Tarihi Yapıların Yeniden Kullanılmasında Yapı-İşlev Uyumu: Rize Müzesi Örneği," Tarih, Kültür ve Sanat Araştırmaları Dergisi, c. 7, s. 5, 2018, s.510523.

Karpat, Kemal, Osmanlı Nüfusu (1830-1914) Demografik ve Sosyal Özellikleri, İstanbul, 2003.

KKVE 1 (Kırklareli Kültür Varlıkları Envanteri), Envanter No: 39-01-764, 2021. 
KKVE 2 (Kırklareli Kültür Varlıkları Envanteri), Envanter No: 39-01-749, 2021.

Kıvılcım, Ecehan, "Geleneksel Konutta İşlevsel Dönüşümün Mekânsal Bağlamda İrdelenmesi: Denizli Konyalıoğlu Evi örneği," Ege Mimarlık Dergisi, c.2, s.103, 2019, s. 50-55.

Kuban, Doğan, Mimarlık Kavramları Tarihsel Perspektif İcinde Mimarlığın Kuramsal Sözlüğüne Giriş, İstanbul, Türkiye: Yem Yayın, 2014.

Mısırlısoy, Damla; Günçe, Kağan, "A Critical Look to the Adaptive Reuse of Traditional Urban Houses in the Walled City of Nicosia," Journal of Architectural Conservation, vol. 22, no. 2, 2016, p. 149-166.

Minsolmaz Yeler, Gülcan; Özek, Veyis, "Geleneksel Konut Mimarlığının Biçimlenişinde İklim Faktörünün Değerlendirilmesi," Ekolojik Mimarlık ve Planlama Ulusal Sempozyumu, Antalya, Türkiye, 2007, s. 125-132.

Özker, Serpil, "Geleneksel Dokunun Değişimi: Ayvalık Evleri," IDA: International Design and Art Journal, c.2, s.2, 2020, s. 212-227.

Saatçi, Suat; Uluengin, Bülent, Kırklareli ve Geleneksel Evleri, 1. Baskı, İstanbul, Türkiye: Mimar Sinan Güzel Sanatlar Üniversitesi Yayınları 822, 2016.

Sağlamcı Şahin, Serap, Kırklareli'nin Tarihsel Gelişimi İçinde Yayla Mahallesinin Çözümlenmesi ve Koruma Önerileri, Yüksek Lisans Tezi, Mimarlık Bölümü, Yıldız Teknik Üniversitesi, İstanbul, Türkiye, 2000.

Selçuk, Mustafa, Binaların Yeniden İşlevlendirilmesinde Mekânsal Kurgunun Değerlendirilmesi, Doktora Tezi, Mimarlık Bölümü, Selçuk Üniversitesi, Konya, Türkiye, 2006.

Tandoğan, Elif, Kırklareli Konut Yerleşimi Üzerine Bir Inceleme, Yüksek Lisans Tezi, Mimarlık Bölümü, Mimar Sinan Güzel sanatlar Üniversitesi, İstanbul, Türkiye, 2000.

Tanrısever, Canan; Saraç, Ömer; Aydoğdu, Aydoğan, "Yeniden İşlevlendirilen Tarihi Yapıların Sürdürülebilirliği,” Akademik Bakış Dergisi, s. 54, 2016, s.1068-1082.

Toptaş, Barış, Kırklareli Merkez İlçe ve Köylerindeki Gayrimüslim Eserleri, Yüksek Lisans Tezi, Trakya Üniversitesi, Sanat Tarihi Bölümü, Edirne, Türkiye, 2012.

Türker, Canan, Binaların Yeniden İşlevlendirilmesinde Mekânsal Kurgunun Kültür ve Eğlence Merkezi Üzerinden Değerlendirilmesi (Bomontiada Örneklemesi), Yüksek Lisans Tezi, Mimarlık Bölümü, Mimar Sinan Güzel Sanatlar Üniversitesi, İstanbul, Türkiye, 2019.

Tüz, Özlem, "Yiyecek İçecek İşletmelerinde Rekabet Edilebilirlik: Mimari Bir Bakış Açısı," Journal of Tourism and Gastronomy Studies, c. 5, s. 1, 2017, s. 137-146.

Uyar, Mevlüt, "Turistik Ürün Olarak Yerel Mutfağın Turist Tiplerinin Seyahat Motivasyonu ve Seyahat Deneyimlerine Etkisi Üzerine Bir Değerlendirme," Journal of Tourism and Gastronomy Studies, c. 9, s. 1, 2021, s. 236-252. 
Var, Elif Berna; Kobayashi, Hirohide, "Possibility of Conserving Vernacular Houses in The Rural Areas of Trabzon, Turkey," Journal of Architectural Conservation, vol. 25, no. 1-2, 2019, pp. 72-89.

Yaldız, Esra; Asatekin, N. Gül, "Anıtsal Yapıların Yeniden Kullanımında İşlevsel Adaptasyonun, Mekânsal Analiz Yolu İle Değerlendirilmesi," Ortadoğu Teknik Üniversitesi Mimarlık Fakültesi Dergisi, c. 33, s. 2, 2016, s.161-182.

Yannakopulu, İoannu S., Saranta Eklesies, Selanik, Yunanistan: Pahuli-Yapuli Anonim Ortaklığı Yayını, 1994.

Yeler, Soner; Minsolmaz Yeler, Gülcan, "Sakinlerinin Anılarında Yayla Mahallesi," Bir Varmış Bir Yokmuş Toplumsal Bellek, Mekân ve Kimlik Üzerine Araştırmalar," Derleyenler: Tahire Erman, Serpil Özaloğlu, 1. baskı, İstanbul, Türkiye: Koç Üniversitesi Publications, 2017, s. 211-221. 